The Oak-Hornbeam Woods of Hertfordshire Parts I and II Author(s): E. J. Salisbury

Source: Journal of Ecology, Vol. 4, No. 2 (Jun., 1916), pp. 83-117

Published by: British Ecological Society

Stable URL: http://www.jstor.org/stable/2255327

Accessed: 27-06-2016 09:31 UTC

Your use of the JSTOR archive indicates your acceptance of the Terms \& Conditions of Use, available at

http://about.jstor.org/terms

JSTOR is a not-for-profit service that helps scholars, researchers, and students discover, use, and build upon a wide range of content in a trusted digital archive. We use information technology and tools to increase productivity and facilitate new forms of scholarship. For more information about JSTOR, please contact support@jstor.org.

Wiley, British Ecological Society are collaborating with JSTOR to digitize, preserve and extend access to Journal of Ecology 


\title{
THE OAK-HORNBEAM WOODS OF HERTFORDSHIRE PARTS I AND II
}

\author{
By E. J. SALISBURY
}

(With Plates $I X$ and $X$ and five Figures in the Text)

Contents

Part I. General and Introductory.

(1) Historical Evidence and Status of the OakHornbeam Woods . . . . . . . 84

(2) Climatic Conditions . . . . . . . . 87

Part II. The Quercus robur-Carpinus Woods.

(1) General . . . . . . . . . . . 88

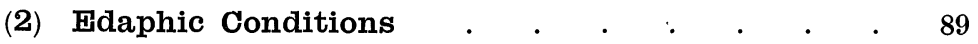

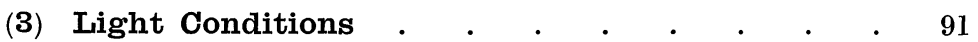

(4) The Flora of the Uncoppiced Wood. . . . 98

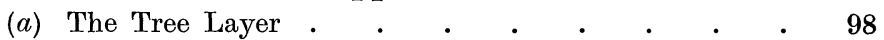

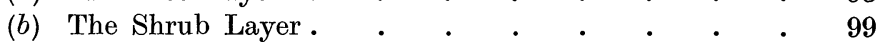

(c) The Ground-flora. . . . . . . . 101

(d) Marginal and Path-floras . . . . . . . 106

(e) Competition . . . . . . . . . . . . 109

$(f)$ The Cryptogamic Flora . . . . . . 110

(g) Exposure . . . . . . . . , 111

(5). The Flora of the Coppiced Wood . . . . 112

(a) Character of the Coppice-flora . . . . . . 112

(b) Acidity . . . . . . . . . . . . . 114

(c) Other Effects of Coppicing . . . . . . . . 114

(d) Effect of Coppicing on Soil-temperature . . . 115

(6) Comparison with the Oak-Hazel Woods. . . 116

(7) Conclusion. Summary of Societies . . . . 117

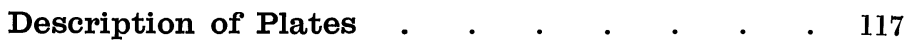

\section{Part I. General and Introductory}

The subject-matter of the present paper is based chiefly upon detailed observations made during the past five years. In the course of the investigation most of the more important woods in Hertfordshire have been visited. Observations of a general character have extended over a much longer period. The author is glad of this opportunity of expressing his great indebtedness to the Rt Hon. the Marquis of Salisbury, Lieut.-Col. A. D. Acland, 
Mrs Burns, Mr H. B. Cox, Mr Roger Cunliff, Mr G. Levinge Whately, and other owners and tenants for the free access to their woods which they have so generously afforded. The work has also been greatly facilitated by the readiness with which the agents of the estates visited and also the keepers have afforded information on various points.

\section{(1) Historical Evidence and Status of the Oak-Hornbeam Woods.}

The county of Hertford is in the main an agricultural district, as a consequence of which the area occupied by woodland is not large. The Board of Agriculture returns for 1905 show however that at that time 26,568 acres were occupied by woods of which 3724 acres represent areas afforested since 1881. By far the larger part of these woods are oak woods, dominated either by Quercus robur or Quercus sessiliflora, the former being associated with the heavier clays and clayey loams whilst the latter is mainly found on the lighter loams and sandy soils. In a large proportion of the oak woods the shrublayer is extensive and periodically coppiced. It is quite clear from documentary evidence that the whole of Hertfordshire was at one time very densely wooded and that the present woods and copses are mere relics of the former forests. Thus in Domesday Book (ca. 1086) Hertfordshire, with its area of 611 sq. miles, is given as affording pannage for 30,720 swine, a large number, since Essex, with an area of 1657 sq. miles, and which was almost continuous forest, is given as only having woodland enough to feed 92,991 swine. In an early manuscript, entitled "The Characteristics of Counties," published in Hearne's edition of Leland's Itinerary, Hertfordshire is referred to as "ful of wode." We are here only concerned with a portion of the Hertfordshire woodlands, namely the oak-hornbeam woods, in which the undergrowth consists mainly of Carpinus betulus. This type of oak wood is here described in detail for the first time. The remarks which have been made above with respect to Herts. woodlands in general probably apply with equal force to the particular type we are considering. Thus we find that the areas which are now occupied by small and scattered oak-hornbeam copses formerly supported large numbers of swine (e.g. Wheathampstead 400 swine, Sandridge 300 swine). It is particularly in the south-east of the county that the hornbeam becomes most abundant, associated with the Quercus sessiliflora woods. This fact was pointed out by Coleman and Webb". "In the Lea division of the county, especially in the south, it (the hornbeam) forms the principal part of the underwood, hence we may name this district the Regio Carpini." In the west the woods are mostly oakhazel, whilst between these two types lie the Q. robur-Carpinus woods (Fig. 7).

Kalm², too, states that between Cheshunt and Bell Bar "in some places there were hornbeam-trees enough six feet high and tolerably thick. The

1 "Flora Hertfordiensis," p. 270.

2 "En Resa till Norra America...af Pehr Kalm," Stockholm, 1753-56 p. 184. 
tops were cut for fuel, otherwise they were of no particular use." Again at Little Gaddesden, where the woods at the present time are mostly oak-hazel, he states "the hornbeam was here very rare ${ }^{1}$."

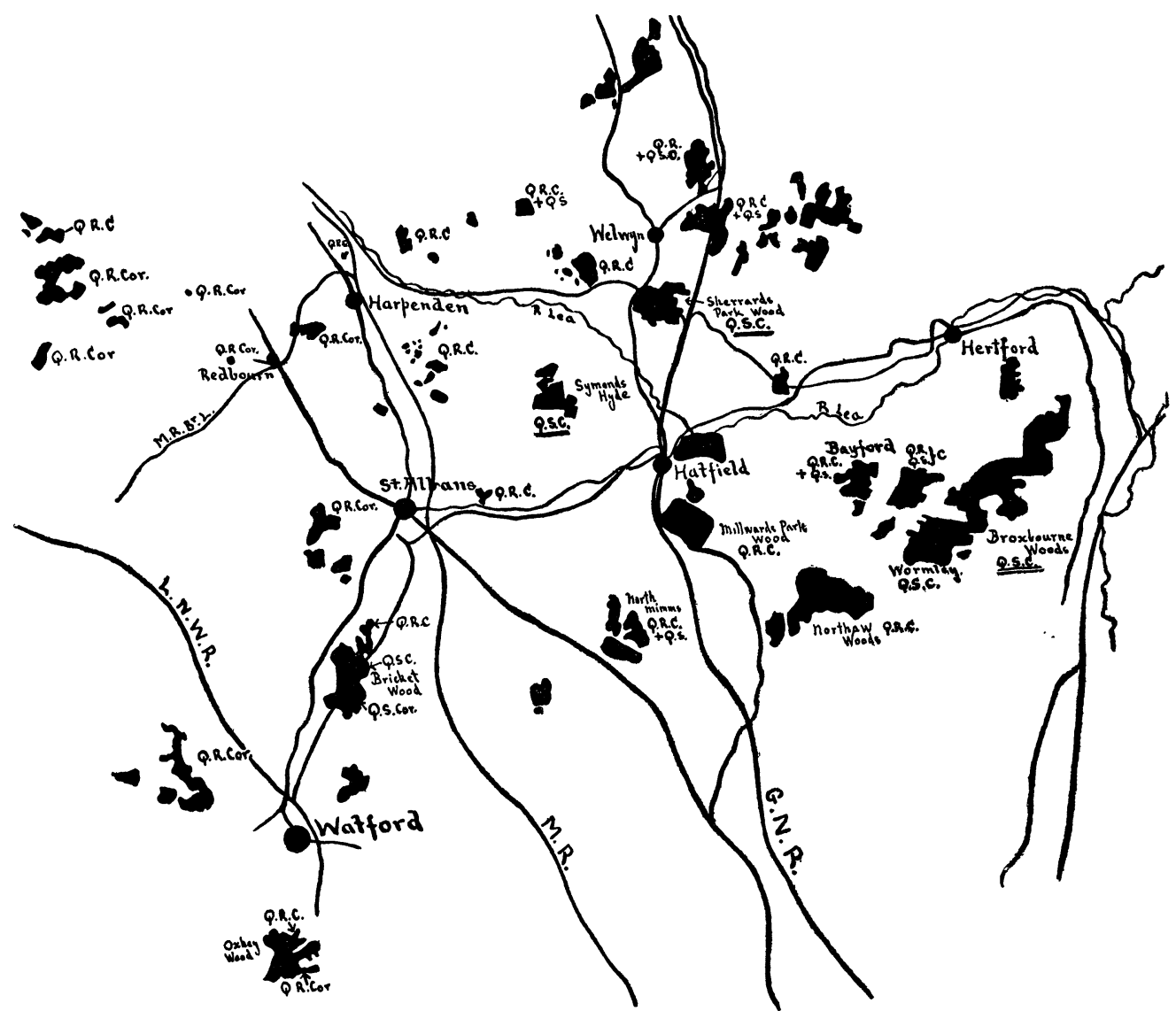

FIG. 7. Map of a portion of Hertfordshire showing the distribution of the different types of woodland. The Quercus robur-Corylus (Q.R.Cor.) woods are situated chiefly in the west and the Q. sessiliflora-Carpinus woods (Q.S.C.) to the south-east. Between the two lie the Quercus robur-Carpinus woods (Q.R.C.) dealt with in Part II.

The question naturally arises as to whether the hornbeam undergrowth is a natural product or the result of planting. That planting of hornbeam was practised is certain. Thus Ellis ${ }^{2}$, who lived at Little Gaddesden, writes, "This (the hornbeam) is in great reputation for both copsehedge and wood and is planted in many parts, but more abundantly about Whethamsted in this County." The natural character of this type of undergrowth is

1 The author is indebted, for this translation from the Swedish original, to Dr B. Daydon Jackson.

2 "The Timber Tree Improved," London, 1742, p. 71. 
however supported by the following facts. (1) Association with definite types of soil. (2) The replacement of Carpinus by Corylus or Sambucus in different parts of the same wood, where there is a local change in the soilconditions. (3) A ground-flora that differs in composition from that of the oak-hazel woods. (4) The occurrence of rare or local species, such as do not occur in woods known to be of recent origin. (5) The presence of a number of associated shrubs. (6) The occurrence of oak-hornbeam woods on similar soil in Essex, Kent and Middlesex.

These points will be dealt with in the sequel, but with regard to the first we may note that Schlich" states that "loams, sandy soils rich in humus, and marls suit it best." According to Correvon" "il recherche les sols argilosablonneux frais et permeables." Loudon ${ }^{3}$ also mentions that the hornbeam will not thrive on chalk. It is clear then that both in England and on the Continent the hornbeam naturally occurs on the lighter types of soil. On the other hand the hazel is commonly found on heavy types of soil and on soils rich in calcium carbonate.

The hornbeam woods of Hertfordshire are likewise associated with the lighter types of non-calcareous soil. Furthermore in these woods the hazel is often abundant, where the soil becomes heavy, and even occurs as a pure undergrowth, or associated with Sambucus, where the soil is calcareous or very wet.

The oak-hornbeam wood finds a place in the enumeration of British woodlands, given by Moss $^{4}$, an inclusion that was adversely criticised by Tansley ${ }^{5}$ on the grounds that "there is no evidence that the presence of the hornbeam modifies the associated vegetation." Whether we are dealing however with the chief types of woodlands or their sub-types, the groundflora is not merely dependent upon the character of the tree and shrub layer, but trees, shrubs and ground-flora, constituting the ecological assemblage, are together an expression of the combined influences of soil, climate, and situation, as well as the interaction of the plants themselves. If, therefore, it can be shown that the presence of a hornbeam shrub-layer is associated with other floristic differences, whether in kind or relative amount, and that these can moreover be correlated with different edaphic or climatic conditions or both, we shall be justified in regarding the oak-hornbeam wood as a definite sub-type, even if it were not true that the change in undergrowth itself probably affects the ground-flora.

1 "Manual of Forestry," 2, p. 334.

2 "Nos Arbres," Paris, 1906, p. 243.

3 "Encyclopedia of Trees and Shrubs," London, 1842, p. 918.

4 "Vegetation of the Peak District," Cambridge, 1913, p. 39.

5 This JournaL, 1, 1913, p. 278. 


\section{(2) Climatic Conditions'.}

The mean annual temperature of Hertfordshire deduced from records extending over a period of 25 years is $48 \cdot 4^{\circ} \mathrm{F}$. $\left(9 \cdot 1^{\circ} \mathrm{C}\right.$.). The monthly mean and the range during the same period is given in Table I. The means show

\section{TABLE I. Teimperature}

$\begin{array}{llcc}\text { Months } & \text { Mean } & \text { Average Max. } & \text { Average Min. } \\ \text { Jan. } & 37 \cdot 3^{\circ} \mathrm{F} . & 42 \cdot 2^{\circ} \mathrm{F} . & 32 \cdot 4^{\circ} \mathrm{F} . \\ \text { Feb. } & 38 \cdot 2 & 43 \cdot 8 & 32 \cdot 5 \\ \text { March } & 41 \cdot 1 & 48 \cdot 2 & 34 \cdot 0 \\ \text { April } & 46 \cdot 1 & 54 \cdot 6 & 37 \cdot 4 \\ \text { May } & 51 \cdot 0 & 61 \cdot 0 & 42 \cdot 8 \\ \text { June } & 57 \cdot 9 & 67 \cdot 0 & 48 \cdot 7 \\ \text { July } & 61 \cdot 3 & 70 \cdot 5 & 52 \cdot 1 \\ \text { Aug. } & 60 \cdot 6 & 69 \cdot 5 & 51 \cdot 7 \\ \text { Sept. } & 56 \cdot 5 & 65 \cdot 0 & 48 \cdot 0 \\ \text { Oct. } & 49 \cdot 0 & 55 \cdot 9 & 42 \cdot 1 \\ \text { Nov. } & 42 \cdot 8 & 48 \cdot 5 & 37 \cdot 2 \\ \text { Dec. } & 38 \cdot 6 & 43 \cdot 5 & 33 \cdot 7 \\ \text { Year } & 48 \cdot 4 & 55 \cdot 8 & 41 \cdot 0\end{array}$

that January is the coldest and July the warmest month, whilst between the two the mean temperature shows an upward gradient which becomes pronounced from March onwards. The mean annual rainfall for the 70 years 1840-1909 is 26.04 inches, the driest months being February, March and April. Table II gives the monthly means and the average number of days on which more than 0.01 inch of rain fell during the period 1870-1909.

\section{Table II. Rainfall and Humidity}

$\begin{array}{lccc}\text { Months } & \begin{array}{c}\text { Mean Rainfall, } \\ 1840-1909\end{array} & \begin{array}{c}\text { No. of days, } \\ 1870-1909\end{array} & \begin{array}{c}\text { Humidity }(\%), \\ 1887-1911\end{array} \\ \text { Jan. } & 2 \cdot 17 & 15 & 91 \\ \text { Feb. } & 1 \cdot 66 & 14 & 88 \\ \text { March } & 1 \cdot 71 & 14 & 84 \\ \text { April } & 1 \cdot 69 & 13 & 76 \\ \text { May } & 2 \cdot 01 & 13 & 73 \\ \text { June } & 2 \cdot 14 & 12 & 73 \\ \text { July } & 2 \cdot 46 & 13 & 71 \\ \text { Aug. } & 2 \cdot 47 & 14 & 74 \\ \text { Sept. } & 2 \cdot 22 & 12 & 80 \\ \text { Oct. } & 2 \cdot 96 & 17 & 87 \\ \text { Nov. } & 2 \cdot 46 & 16 & 91 \\ \text { Dec. } & 2 \cdot 09 & 16 & 92 \\ \text { Year } & 26 \cdot 04 & 169 & 82\end{array}$

In comparing the vegetation of the oak woods here described with the Quercus robur woods described by $\mathrm{Moss}^{2}$, Wilson ${ }^{3}$ and Adamson 4 , it must be noted that the mean annual rainfall for Kent and Cambridgeshire is

1 These data are compiled from the account by Hopkinson ("The Climate of Hertfordshire," Trans. Herts. Nat. Hist. Soc., 15, Part Iv, 1915, pp. 195-206).

2 "Geographical Distribution of Vegetation in Somerset," London, 1907.

3 "Plant-distribution in the Woods of North-east Kent," Ann. of Bot. 25, 1911.

4 "An Ecological Study of a Cambridgeshire Woodland," Journ. Linn. Soc. 40, 1912. 
lower than that in Hertfordshire, whilst that of Somerset is higher. The mean annual temperature in all three counties is higher than that of Hertfordshire.

\section{TABLe III. Dates of Flowering of Plants ${ }^{1}$}

\begin{tabular}{lcccccccc}
\multicolumn{1}{c}{ Plant } & \multicolumn{4}{c}{ Average for 20 years, 1891-1910 } & \multicolumn{3}{c}{ Aver. 37 years, } \\
& Eng. S.W. & S. & Mid. & E. & N.W. & N.E. & Hertfordshire \\
Corylus avellana & 40 & 35 & 43 & 36 & 44 & 50 & 30 \\
Anemone nemorosa & 86 & 83 & 89 & 88 & 92 & 94 & 83 \\
Prunus spinosa & 92 & 98 & 100 & 99 & 104 & 109 & 95
\end{tabular}

Phenological observations (see Table III) show that Hertfordshire is slightly earlier than the south of England.

\section{Part II. The Querous Robur-Carpinus Woods}

\section{(1) General.}

The hornbeam shrub-layer appears to be typically associated with the Quercus sessiliflora woods of Hertfordshire, and the Quercus robur-Carpinus woods, with which the present part deals, are probably to be regarded as a type transitional to the Quercus robur-Corylus woods. These transitional woods are often of no great area, being in many cases not more than 6 to 20 acres in extent. The small size and scattered distribution of such copses is a further argument in favour of their being relics of larger woods. In many cases they probably owe their immunity from the general conversion of woods into arable land, to the fact that they are often situated where the contour of the surface shows abrupt changes. Owing to the difficulties of ploughing, etc., such would naturally be the last areas to pass into cultivation.

It is chiefly smaller woods of the Quercus robur-Carpinus type, varying in extent from 3 to 60 acres, which have been critically examined and in this way an aggregate of over 100 acres of woodland has been under continued observation at all seasons of the year. On these observations the frequencies are mainly based, and it may be emphasised that such data are only reliable when, as in the present case, the same areas are repeatedly visited throughout the vegetative period. In addition, however, a very much larger area (some 1200 acres) of this type comprising woods from one-fifth to over half a square mile in extent have been also examined in detail at less frequent intervals. The lists of species embody the records thus obtained and also such additional ones as are given in Pryor's Flora of Hertfordshire (London, 1887).

1 Compiled from Fopkinson, "Phenological Observations in Herts. for 1913" (Trans. Herts. Nat. Hist. Soc. 15, 1915, p. 243), and Clark and Hooker, "Report on Phenological Observations for 1911" (Q. J. Roy. Met. Soc. 28, 1912). 


\section{(2) Edaphic Conditions.}

The Quercus robur-Carpinus woods occur in all the cases examined on the lighter clays and stiff loams. Most commonly these belong to the deposit known as clay with flints which forms a layer of very variable thickness overlying the chalk. It is therefore of interest to note that Wilson ${ }^{1}$ records the occurrence of Quercus robur woods on the clay with flints of Kent in which Carpinus and Fraxinus are the most abundant members of the undergrowth. Owing to the piped character of the underlying chalk not only are the changes in depth often very abrupt, but, as has been pointed out by Woodward ${ }^{2}$, the soil in consequence probably dries more readily after heavy rainfall.

In general the chalk subsoil is seldom less than three feet below the surface. For the first 6 to 12 inches the clay is more or less flocculated, probably owing to the high acidity (vide infra). Below this depth it passes into a yellow and stiffer clay that at about $2 \frac{1}{2}$ feet becomes quite colloidal. The upper layers sometimes contain so large a proportion of flints, an inch or more in diameter, that it is often difficult to insert a trowel for a depth of more than a few inches. In a sample of soil from Stocking's Wood the stones over $3 \mathrm{~mm}$. in diameter represented 34.5 per cent. of the dry weight. The mechanical composition of the soil is somewhat variable but shows much the same proportions of coarse and fine particles as the clay with flints of Kent.

\section{Table IV. Composition of Woodland Soils (Quercus robur-Carpinus)}

$\begin{array}{ccc} & \text { Stocking's Wood } & \text { Langley Wood } \\ \text { Fine gravel (over } 1 \mathrm{~mm} \text {.) } & 7.8 \% & 6.5 \% \\ \text { Coarse sand (0.13-1 mm.) } & 3.5 \% & 6.9 \% \\ \text { Fine sand, silt and clay } & 84.2 \% & 61.9 \% \\ \text { (under 0.13 mm.) } & & \end{array}$

Comparison shows that the soil in Quercus robur-Corylus woods usually contains a smaller proportion of gravel and coarse sand, whilst that of the Quercus sessiliflora woods contains a much higher percentage.

Humus. The organic content of the soil shows considerable variation even in the same wood and this is accompanied by variation in the character of the ground-flora. In general the humus is seldom below 7.5 per cent. and rarely above 15 per cent. of the dry weight (cf. Table XI, p. 103).

Water-content. The natural water-content has been determined for a number of woods at different periods of the year. These were based on composite samples placed in tins immediately upon collection, the soil was then dried at $100^{\circ} \mathrm{C}$. till a constant weight was obtained. The samples were taken to a depth of 6 inches after the raw humus and vegetation had been

1 Loc. cit.

2 "Summary of Progress of the Geological Survey of the United Kingdom," London, 1903. Journ. of Ecology IV 
removed. It is clear that only the results from samples collected on the same day are strictly comparable, though even such may be misleading unless topographical differences are taken into consideration. For example, in woods occupying the slope of a hill the water-content may only be reached after prolonged rainfall (cf. Pudler's Wood, Table V, Series 1 and 3). Whilst artificial water-contents afford a basis for comparison with the results of other workers, they are open to the very grave objection that the values are unrelated to such important factors as slope of surface, shelter, distance from permanent water-table, capillarity, etc. The natural water-content, however, gives us a resultant of all these influences as they occur in situ.

\section{Table V. Natural Water-contents (of composite soil-samples)}

Series 1, all collected on the same day after heavy rainfall, Nov. 13th, 1915

\begin{tabular}{|c|c|c|c|c|c|c|}
\hline \multicolumn{4}{|c|}{ Locality } & \multicolumn{2}{|c|}{ Sample } & Water-conte \\
\hline Langley Wood & $\cdots$ & $\ldots$ & $\cdots$ & $a$ & & $40 \cdot 12$ \\
\hline & $\cdots$ & $\ldots$ & $\ldots$ & $b$ & & $40 \cdot 3$ \\
\hline Cutts Green Wood & $\ldots$ & ... & $\ldots$ & $a$ & & $40 \cdot 2$ \\
\hline Püller's "Wood" & $\cdots$ & $\begin{array}{l}\cdots \\
\ldots\end{array}$ & $\begin{array}{l}\cdots \\
\ldots\end{array}$ & $\begin{array}{l}b \\
a\end{array}$ & & $\begin{array}{l}40 \cdot 3 \\
34 \cdot 7\end{array}$ \\
\hline 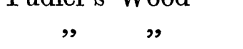 & $\cdots$ & $\cdots$ & $\cdots$ & $\begin{array}{l}a \\
b\end{array}$ & & $35 \cdot 4$ \\
\hline \multicolumn{7}{|c|}{ Series 2, March 16th, 1916} \\
\hline \multicolumn{5}{|c|}{ Langley Wood (Scilla, Anemone, Mercurialis)... } &. & $39 \cdot 1$ \\
\hline \multirow{2}{*}{\multicolumn{5}{|c|}{ Well Wood (coppiced, Anemone, etc.) }} & $\cdots$ & $37 \cdot 4$ \\
\hline & & & & & ... & $41 \cdot 9$ \\
\hline \multicolumn{5}{|c|}{ Secret Spring Wood (Anemone, etc.) } & & $40 \cdot 9$ \\
\hline \multicolumn{5}{|c|}{ Eight Acre Wood (Scilla, Anemone, Mercurialis) } & & $44 \cdot 4$ \\
\hline \multicolumn{5}{|c|}{ Marshall's Wood (Mercurialis, Scilla, etc.) } & & $46 \cdot 7$ \\
\hline
\end{tabular}

Series 3. Samples collected on various dates Locality Sample Water-content

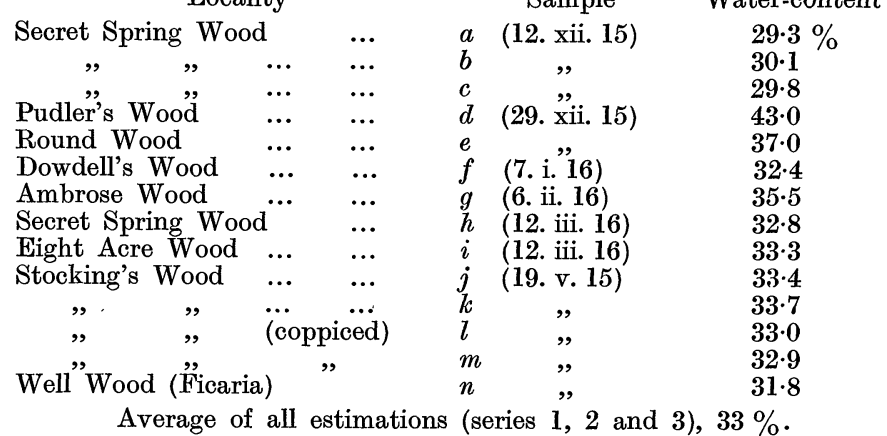

From the data given in Table V (cf. also Table XII, p. 104) it will be seen that during the winter and spring the average water-content is about 33 per cent. as calculated upon the dry weight, whilst the maximum is from 40-56 per cent. Broadly the estimations for different woods on the same day are very close and in no case amount to more than the variation associated with differences in the vegetation in one and the same wood. The minimum 
water-content was recorded during the drought of 1915 towards the end of which as little as 19 per cent. of water was present.

Acidity. The author is indebted to Dr H. B. Hutchinson for the determinations of soil-acidity. These are expressed as the amount of lime required to neutralise, and the method employed is that described by Hutchinson and MacLennan in their paper on the lime requirements of soils ${ }^{\mathbf{1}}$.

TABLE VI. Soil-acidities (composite samples from Quercus roburCarpinus woods)

\begin{tabular}{|c|c|c|c|c|c|}
\hline \multirow{2}{*}{\multicolumn{2}{|c|}{$\begin{array}{c}\text { Wood } \\
\text { Secret Spring }\end{array}$}} & Condition & \multirow{3}{*}{$\begin{array}{c}\text { Character of vegetation } \\
\text { Open (Anemone) } \\
\text { Deep shade }\end{array}$} & \multirow{2}{*}{$\begin{array}{r}\text { Acidity } \\
0.5 \%\end{array}$} & Acidity Humus \\
\hline & & Uncoppiced & & & $1: 17 \cdot 4$ \\
\hline " & " & " & & & $1: 24 \cdot 5$ \\
\hline$"$ & " & ” & Mercurialis & $0 \cdot 34$ & $1: 32 \cdot 6$ \\
\hline$"$ & ", & , & Dense Mercurialis & $0 \cdot 32$ & $1: 52$ \\
\hline$"$ & " & " & & $0 \cdot 72$ & $1: 25 \cdot 4$ \\
\hline Stockin & s"Wood & ” & $\begin{array}{l}\text { Scilla, Galeobdolon, Mercurialis } \\
\text { Scilla, Anemone. Mercurialis }\end{array}$ & $0 \cdot 38$ & $1: 24 \cdot 7$ \\
\hline Secret & pring & Coppiced & Holcus, Anthoxanthum, Cnicus & $\begin{array}{l}0.44 \\
0.52\end{array}$ & $1: 20.9$ \\
\hline " & , & ” & & $0 \cdot 48$ & $1: 19$ \\
\hline " & , & , & ba, Scilla & 0.58 & $1: 19$ \\
\hline ", & , & ," & Mercurialis, Scilla & 0. & $1: 40$ \\
\hline 77 & ", & ", & Mercurialis, Ficaria & $0 \cdot 31$ & $1: 41$ \\
\hline 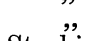 & , & ", & Near edge (Holcus, Anemone) & $0 \cdot 62$ & $1: 14 \cdot 5$ \\
\hline Stockin & 's Wood & ", & Composite from various types & $0 \cdot 46$ & \\
\hline $\begin{array}{l}\text { Well W } \\
\text { Averag }\end{array}$ & & Uncoppi & 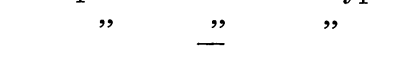 & $\begin{array}{l}0 \cdot 54 \\
0 \cdot 44\end{array}$ & $\begin{array}{l}1: 15 \\
1: 29 \cdot 4\end{array}$ \\
\hline ", & & Coppiced & - & 0.47 & $1: 24 \cdot 2$ \\
\hline
\end{tabular}

Table VI shows that the soil-acidity is high, corresponding to or even in excess of the higher acidities of a Heath in the same region ${ }^{2}$. Since the effect of acidity is dependent upon the concentration the ratio of acidity to organic material gives us a measure of the normal acidity of the soil-solution.

\section{(3) Light Conditions.}

For the purpose of this paper the light-intensities were estimated by means of an actinometer. The time of exposure required for the sensitised paper to reach a standard tint being, as shown by Bunsen and Roscoe, inversely proportional to the intensity of the photochemical rays. Exposures of orthochromatic plates with yellow screens based upon such light-estimations seem to justify the assumption that the effect of different degrees of shading does not materially alter the relative proportions of the light of different wave-lengths. We may therefore regard the light-values obtained by means of the actinometer as approximately proportional to the photosynthetic value of the light. As is well known, however, the light-intensity on a sunny day is in excess of that which the green leaf is capable of utilising ${ }^{3}$.

1 "Studies on the Lime-requirements of certain soils," Journ. Agric. Sci. 7, 1915, pp. 75-105.

2 Futchinson and MacLennan, loc. cit. p. 102.

3 Brown and Fscombe, "On the Physiological Processes of Green Leaves," Proc. Roy. Soc. 76, 1905, pp. 54-55. 
Blackman and Matthaei ${ }^{1}$ estimated that, to prevent photosynthetic waste in sunshine, an increase of the carbon dioxide content of the air six-fold would be necessary. Since, as numerous investigators have shown, the assimilatory activity increases proportionately to the light-intensity, a diminution of the light to one-sixth would result in illumination becoming the limiting factor. In all cases the intensity of the diffuse light outside the wood was first estimated, and this was repeated after testing the intensity of the diffuse light in the interior of the wood. The light-intensity is throughout expressed as a percentage of the diffuse light-intensity in the open. Since diffuse light is approximately one-third the intensity of direct sunlight, a doubling of the carbon dioxide content of the air would result in the diffuse lightintensity becoming the limiting factor. Ebermayer working on the air in beech and pine woods found that the atmosphere two metres above the soil contained during the summer twice the amount of carbon dioxide of the air outside, i.e. $0 \cdot 08$ per cent., whilst the air in the humus layer contained no less than $0 \cdot 148$ per cent. $\mathrm{CO}_{2}{ }^{2}$. Fodor ${ }^{3}$ and Russell and Appleyard ${ }^{4}$ have shown that the soil-air has a minimum $\mathrm{CO}_{2}$-content during the summer and winter, whilst it attains a maximum during the late spring and autumn. Having regard to the relatively low growth of the social species of the ground-flora and the shelter they produce, the air around them probably has a much higher $\mathrm{CO}_{2}$-content than the air in the open. From the data given above it is probably safe to assume that the diffuse light-intensity in a woodland is always the limiting factor to the photosynthetic activity when it falls below 50 per cent. of the intensity in the open, and very probably even when the diffuse illumination is at a maximum.

Owing to the seasonal changes of the shrub-layer we can clearly distinguish two phases in the light-conditions, namely $(a)$ the light-phase extending from the leaf-fall in autumn to leaf-expansion in spring, and $(b)$ the shade-phase from about the middle of May to autumn. During the former the shading effect mainly depends upon the horizontal branch-canopy of the standards and the bare twigs of the shrubs. The former is however probably more efficient in reducing the intensity than the almost vertically directed branchsystems of the shrub-layer. The intensity during the shade-phase is mainly conditioned by the age of the coppiced shoots.

1 "Experimental Researches in Vegetable Assimilation and Respiration. IV. A Quantitative Study of Carbon Dioxide Assimilation and Leaf-temperature in Natural Illumination," Proc. Roy. Soc. B, 76, 1905, p. 455.

2 "Mitteil. ueb. den Kohlensaeuregehalt der Waldluft und des Waldbodens im Vergl. zu einer nicht bewaldeten Flaeche," Forsch. auf d. Gebiete d. Agric. Physik, 1, 1878, pp. 158-161.

3 "Hygienische Unters. ueb. Luft, Boden, u. Wasser," Braunschweig, 1881.

4 "The Atmosphere of the Soil, its Composition, and Causes of Variation," Journ. Agric. Sci. 7, 1915. 
TABLE VII. Light-intensities (Quercus robur-Carpinus woods)

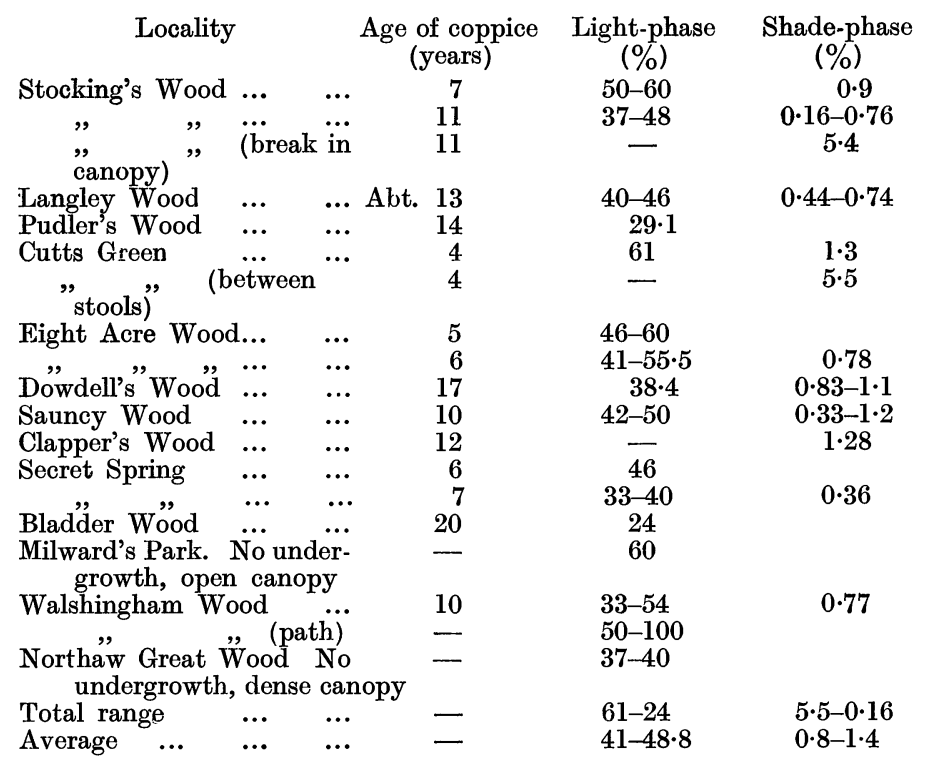

The average intensity during the light-phase (see Table VII) rapidly falls as the undergrowth increases in age, so that during the greater part of the uncoppiced period, which usually lasts for 10 to 14 years, the light-intensity is from 40 to 60 per cent., but, during the last few years before coppicing, the intensity during the light-phase decreases to an average of between 30 per cent. and 45 per cent. of the total diffuse light outside.

During the shade-phase the illumination is much less uniform, varying between 0.16 per cent. and 1.3 per cent. where the canopy is continuous, though it may attain to 5 per cent. where the canopies, formed by adjacent shrubs, meet. Along the paths the light-intensity may be as much as 20 per cent. or even more. For the typically woodland species, which are nearly all vernal, it is the illumination during the light-phase that is important. A study of the light-intensity at the same spot in a wood during the early part of the year (Fig. 8) shows a gradual increase during March, probably due to the increasing altitude of the sun. As the shrubs begin to enlarge during April the intensity decreases and then exhibits a rapid fall during leaf-expansion. In view of the very low intensity of light during the shadephase of an uncoppiced wood it is evident that after the light-phase has ended assimilation can only be carried on very slowly by the leaves of the ground-vegetation. If we compare the light-intensity during the two phases we shall find that during the one it is nearly 35 times as great as during the other. Even plants then such as Mercurialis perennis and Galeobdolon luteum which, in the lighter parts of the wood may retain their leaves 


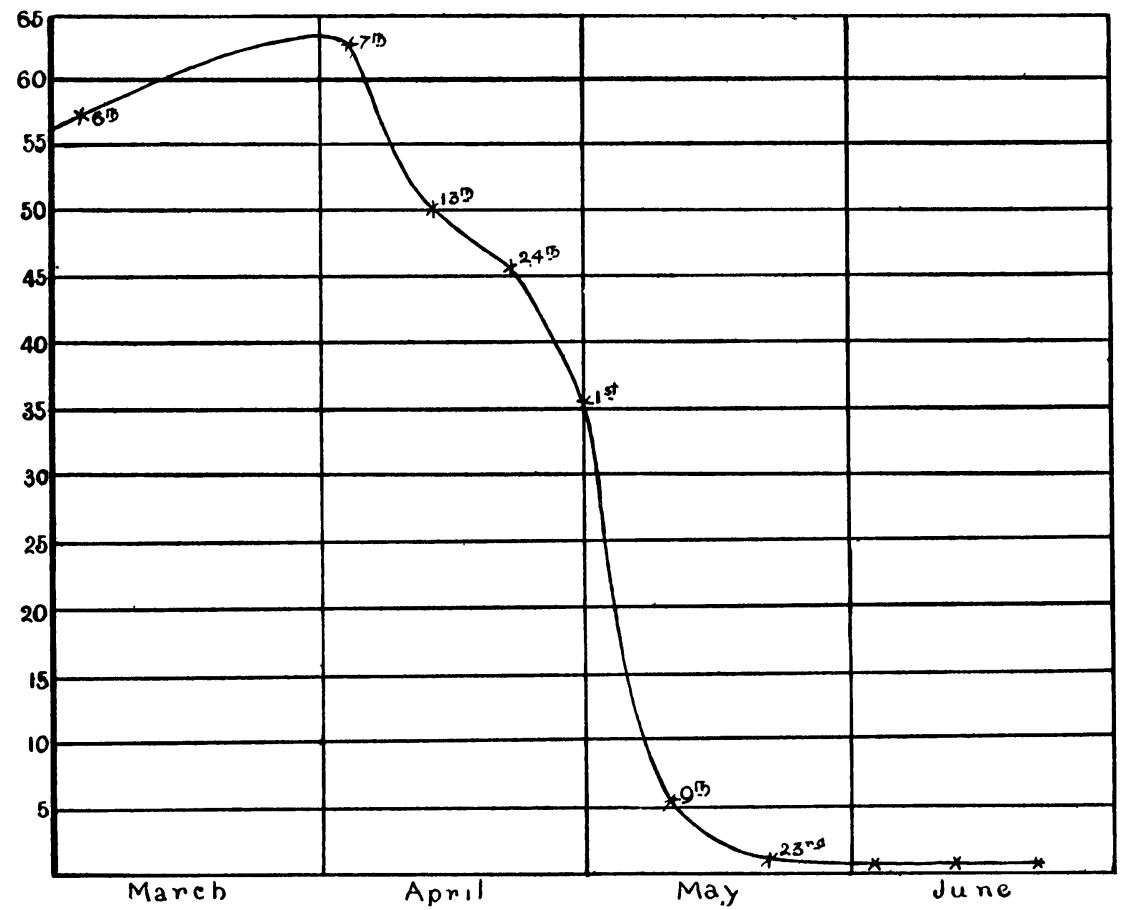

FIG. 8. Diagram showing changes in the light-intensity at one spot in a Quercus roburCarpinus wood.

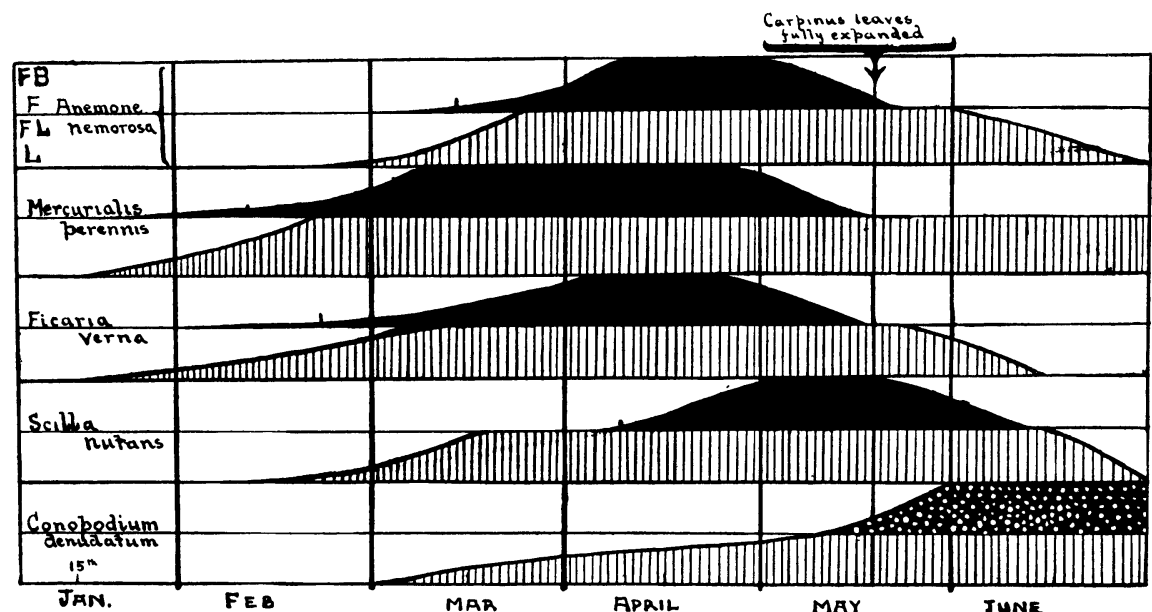

Frc. 9. Diagram showing the period of foliage and flower production for common species of the shade-flora based upon the average of several years. The vegetative period is shown by vertical shading and the flowering period black. F.L., full leaf; F.B., full bloom. The stippling indicates that flowering only occurs in the coppiced wood. 
throughout the summer would, on the most generous computation, only receive during the entire shade-phase about one-fourteenth of the amount of light which reached them during the light-phase.

The period of foliage-formation for the different species is therefore of great importance in determining their capacity for vigorous growth in the interior of the wood. In Fig. 9 the vegetative periods for the more important shade-species are indicated as well as their periods of flower-production. In the case of Ficaria verna, Mercurialis perennis and Primula acaulis the new leaves may have already developed by the middle of January, those of Scilla nutans and Arum maculatum begin to appear about the middle of February, whilst Galeobdolon luteum, Conopodium denudatum and Anemone nemorosa do not usually produce their foliage till early in March. It is therefore significant that Ficaria, Mercurialis and Primula are met with in the deeper shade, whilst Anemone, Conopodium and Galeobdolon are more particularly associated with the better lighted areas. Since the early production of assimilating organs is so important a factor in the nourishment of woodland species it is interesting to note that in some of these plants the last season's leaves often in part persist through the winter. Examples are afforded by Galeobdolon luteum, Primula acaulis, Sanicula europaea, Nepeta glechoma, Stellaria holostea and Viola riviniana. An examination of a wood on January 9th, 13 months after coppicing, where the exposure consequently was still considerable, revealed a number of species with green leaves persisting from the previous season or, in most cases, the product of new growth. These included Ajuga reptans, Ficaria verna, Fragaria vesca, Galeobdolon luteum, Geum urbanum, Holcus lanatus, Hypericum perforatum, Mercurialis perennis, Nepeta glechoma, Orchis mascula, Potentilla fragariastrum, Primula acaulis, Ranunculus auricomus, Rumex condylodes, Sanicula europaea, Stellaria graminea, Veronica chamaedrys and Viola sylvestris. Besides these there were the woodland annuals, namely Galium aparine, Arenaria trinerva and Torilis anthriscus, which it is interesting to note germinate the previous autumn and retain their foliage throughout the winter.

An exception to the above generalisation appears to be afforded by Epipactis violacea which does not produce its leaves until after the inception of the shade-phase and often grows in situations where the canopy is moderately dense. Probably, however, the explanation lies in the fact that the nutrition of this plant is, like so many of the orchids, largely saprophytic.

The early flowering of woodland plants is doubtless related to the necessity of light for their proper development. A study of the flowering period of British woodland plants shows that in general they flower nearly a month earlier than non-woodland species (Fig. 10). As a consequence of this fact the advent of the shade-phase will only affect the production of flowers adversely towards the end of the flowering period. In Oxalis acetosella and Viola spp. the normal flowers are replaced during the shade-phase by 
cleistogamic ones, but in most species flower-production ceases after leafexpansion of the shrub-layer. That flowering is largely dependent upon the photosynthetic activity would appear to be indicated by the fact that shade frequenting species blossom most profusely in a coppiced wood (compare Phot. 8, Plate X, with Phot. 2, Plate IX), and they exhibit a diminishing flower-production as the coppiced shoots increase in size and the illumination during the light-phase decreases. As will be seen from Fig. 8 the light-intensity begins to diminish slightly some time before actual leaf-expansion, hence we

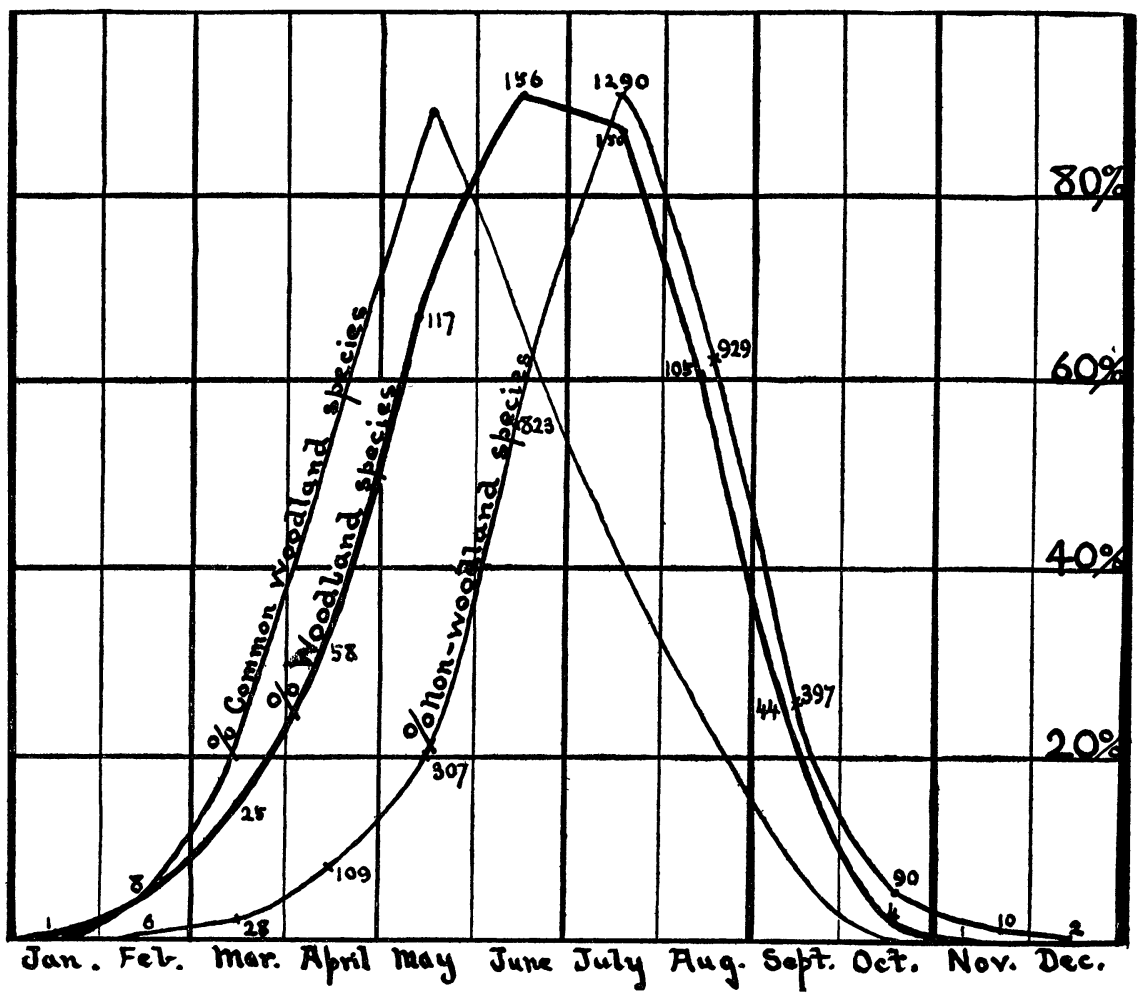

Frg. 10. Diagram showing the percentage of woodland and non-woodland species in the British Flora flowering in the different months.

can understand why it is that Anemone, Galeobdolon and Conopodium, which produce their foliage relatively late, are much more adversely affected than such species as Ficaria verna and Mercurialis perennis. Most woodland species have food-reserves formed in the previous season upon which the production of flowers depends. We can therefore understand why coppicing which usually takes place in January or February does not materially affect flower-production during the same season. In the next year however such plants as Anemone, Conopodium, and Galeobdolon often produce a wealth of bloom that is almost phenomenal (Plate X, Phot. 8). 
The light-phase is then the critical period and the amount and vigour of the ground-flora would appear to be mainly dependent on the intensity of the light at this time. It is a well-known fact that the floor of a pine wood, a box wood or a beech wood is frequently devoid of vegetation except for a few bryophytes and fungi. Light-tests, in woods belonging to these types, reveal the fact that the light-intensity in such woods, during the shade-phase is often not less than in oak woods with a well-grown coppice, in the latter however there is often a considerable vernal ground-flora (see Table VIII).

\section{TABLE VIII. Light-intensities (woods without ground-flora)}

\begin{tabular}{|c|c|c|c|c|}
\hline \multicolumn{3}{|c|}{ Wood } & Light-phase & Shade-phase \\
\hline Pine wood, & Wisley & $\ldots$ & \multicolumn{2}{|c|}{$4.3 \%$} \\
\hline $\begin{array}{l}\text { Box wood, } \\
\text { Beech wood, }\end{array}$ & $\begin{array}{l}\text { Boxhill } \\
\text { Berkhamst }\end{array}$ & tead & & $0.4 \%$ \\
\hline ” & Pitstone & $\ldots$ & $19 \cdot 4 \%$ & $1.4 \%$ \\
\hline ", & Aldbury & $\ldots$ & $40 \%$ & $1.6 \%$ \\
\hline ", & , & $\ldots$ & $38 \%$ & $1 \%$ \\
\hline
\end{tabular}

The absence of ground-flora from such woods is therefore probably due, in the case of the pine and box, to the permanent character of the shadephase. In the case of the beech, to the low intensity during the light-phase and to the fact that the ground-flora does not receive any periodic impetus through the coppicing of an undergrowth. In other words it is the intensity during the light-phase combined with the time-factor which determines the amount of the ground-flora, the intensity during the shade-phase being relatively unimportant. It is in complete accord with this view that even the vernal shade-flora of an oak wood tends to become more and more scanty the longer the coppiced stools remain uncut (Plate X, Phot. 6), and those species that persist do so in spite of the adverse conditions. The longer the latter prevail the more completely do the light-demanding species become eliminated, whilst those which can endure shade will only survive as scattered individuals, particularly near the margin of the wood. Thus in the case of Bladder Wood (Table VII), where the intensity during the light-phase is only 24 per cent. and the coppice-shoots 20 years old, the ground-flora is extremely sparse and large areas are completely bare. Dowdell's (17 years) and Pudler's (14 years) with average light-intensities of 38.4 per cent. and $29 \cdot 1$ per cent. respectively show the same phenomenon in a less marked degree. It is important to note that of these two woods that having the older coppice has the greater paucity of vegetation, although the average light-intensity is higher than that of the younger coppice. This clearly indicates that reduced illumination requires a period of years for the full effect to become manifest and consequently explains the occasional survival of light-demanding species in the interior of woods where the interval between successive coppicings is short. 
In some woods where the tree layer is sufficiently dense to form an almost continuous canopy the shrub layer is very sparse or altogether absent. In such woods the light-intensity during the light-phase may be higher than in those woods with a sparse tree layer and dense shrub layer (e.g. Northaw, Table VII), and yet the ground-flora is usually extremely scanty, whilst that where the shrub layer is dense, unless it be old, is abundant. Here again the time-factor is probably all important, even the shade-enduring species becoming greatly reduced during the long interval between successive fellings. This aspect will be again considered in relation to the effect of coppicing, but we may summarise the results by saying that the ground-flora of the uncoppiced wood is to be regarded, in the main, as a relic from the periodically recurring intervals of increased illumination. Where these have been frequent (short coppice period) the ground-flora is abundant, where infrequent (long coppice period), or at long intervals (felling), the ground-flora is scanty.

\section{(4) The Flora of the Uncoppiced Wood.}

(a) The Tree Layer. The predominating tree in these woods is undoubtedly Quercus robur. The number of standards per acre is not usually large (about 60), and sometimes does not exceed an average of 5 per acre. On the lighter soils occupied by Quercus robur-Carpinus woods occasional specimens of Quercus sessiliflora are usually present. Some, if not all, of these woods in which both species occur are very probably to be regarded as of the Quercus sessitiflora-Carpinus type in which, owing to felling of the original species and the planting of Quercus robur, only a few self-sown relics of Quercus sessiliflora remain. In any case such woods constitute a transition, both as regards the arboreal and herbaceous flora, to the Quercus sessitifloraCarpinus woods proper.

In some of the smaller copses trees of Prunus avium are often nearly as frequent as the oak itself, but this species appears to exhibit a decided preference for the heavier types of soil and is indeed a marked feature of the oak-hazel woods. The ash is also of very general occurrence, expecially in the wetter parts or where the underlying chalk approaches close to the surface. In clearings the ash is often the dominant tree and dense thickets of ash saplings usually occupy disused rides, etc., which have been left uncleared for some time (Plate X, Phot. 5). Ulmus montana though never common is quite characteristic. On the lighter soils and in the mixed woods in which Quercus sessiliflora is present, Betula alba and B. pubescens are both frequent, the white birch being usually the commoner.

Of the smaller trees the most characteristic are Salix cinerea and S. caprea, whilst on the lighter soils Carpinus betulus occurs frequently in this form. Pyrus aucuparia and $P$. torminalis appear to be restricted to those woods in which Quercus sessiliflora is also present. For lists, see Table X. 
(b) The Shrub Layer. The density of the shrub layer is in inverse ratio to the proximity of the standards and, in general, the latter tend to be most numerous on the lighter types of soil. The undergrowth usually consists almost entirely of Carpinus betulus var. provincialis in the form of coppice, but it is important to note that in several woods the hornbeam is, locally, completely replaced by hazel. Striking examples are afforded by Oxhey Woods and North Mimms Woods, in both of these the hazel undergrowth is confined to those areas where, owing to the contour of the surface and the stiff character of the soil, the water-content is high.

\section{TABLE IX. Natural Water-contents}

\begin{tabular}{|c|c|c|c|c|c|}
\hline \multirow[b]{2}{*}{$\begin{array}{l}\text { Wood } \\
\text { ey } \ldots .\end{array}$} & \multirow[b]{2}{*}{$\begin{array}{c}\text { Date } \\
\text { 14. iv. } 16\end{array}$} & \multicolumn{2}{|l|}{ Carp } & \\
\hline & & $\begin{array}{c}\text { Water-content } \\
35 \cdot 4-36 \cdot 8 \%\end{array}$ & $\begin{array}{l}\text { Humus } \\
7.4 \%\end{array}$ & $\begin{array}{c}\text { Water-content } \\
50 \%\end{array}$ & $\begin{array}{l}\text { Humus } \\
11.32 \%\end{array}$ \\
\hline
\end{tabular}

The same feature can also be observed on a small scale in many of the woods where dells have been formed through excavation for chalk. Here hazel almost invariably occupies the slopes, whilst the floor where the soil is shallowest, i.e. nearest the chalk, is frequently marked by a dense growth of Sambucus. Occasionally small copses are even met with in which elder is throughout the predominating member of the undergrowth, but usually this type is very local and confined to the base of slopes or to shallow depressions where, either owing to the proximity of the chalk or the high watercontent, the acidity is relatively low. The occurrence of species, which normally occur on chalk, in damp situations has already been recorded. Thus Moss ${ }^{1}$ writing of the Pennine Woods says, "it seems clear that in any given natural station the abundance of the ash is due to one of two causes, either to a high water-content or to a high lime-content." Amongst the common shrubs found in chalk-scrub we may note Crataegus monogyna, Sambucus nigra, Acer campestre, Ligustrum vulgare, Solanum dulcamara and Rhamnus catharticus as species which are also found quite characteristically in very wet situations. These facts seem to point to acidity as being the chief factor in determining their distribution. For the very dry habitat has at most a low acidity owing to the high lime-content, whilst the wet habitat has a low acidity owing to the dilution of the humic acids. Similarly in the ground-flora we find Mercurialis perennis, usually associated with calcareous soils, also frequenting the damper part; of these acid woodlands (cf. Table VI).

Brambles and honeysuckle are very characteristic but are not usually common except in the mixed woods where, as in the Quercus sessiliflora woods proper, they tend to become abundant. Where the chalk subsoil comes to the surface not only does hazel replace the hornbeam, but such

\footnotetext{
1 "Vegetation of the Peak District," p. 69.
} 
shrubs as maple, dogwood and blackthorn, as well as Clematis vitalba, become much commoner. Prunus institia, Rosa micrantha, and Viburnum opulus are confined to the mixed woods.

\section{TABLE X. List of Trees and Shrubs}

Trees.

\begin{tabular}{|c|c|c|c|c|c|}
\hline \multicolumn{6}{|l|}{ Quercus robur } \\
\hline sessiliflor & & & ... & ... & r-o (lightest soils only). \\
\hline robur $\times$ & Q. se & ssiliflora & $\ldots$ & $\ldots$ & o (mixed woods only). \\
\hline Acer pseudo-plat & anus & ... & $\ldots$ & $\ldots$ & 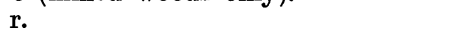 \\
\hline Alnus glutinosa & & $\cdots$ & $\ldots$ & $\ldots$ & r (lighter soils). \\
\hline Betula alba & ... & .. & ... & ... & vr-fc (lighter soils). \\
\hline pubescens & $\ldots$ & & $\ldots$ & $\ldots$ & f (absent from heaviest soils). \\
\hline Carpinus betulus & var. & provinci & & $\ldots$ & r-f. \\
\hline Fagus sylvatica & $\ldots$ & $\ldots$ & $\ldots$ & $\ldots$ & vr-f (light soils or chalk outcrops). \\
\hline Fraxinus excelsio & r... & ... & ... & $\ldots$ & o-f. \\
\hline Populus tremula & var. & sericea & ... & $\ldots$ & o-lf (lighter soils). \\
\hline Prunus avium & $\ldots$ & ... & $\ldots$ & $\ldots$ & f-c. \\
\hline Pyrus aucuparia & $\ldots$ & $\cdots$ & $\ldots$ & ... & r (mixed woods only). \\
\hline " malus & $\cdots$ & ... & ... & ... & $\mathrm{vr}-\mathrm{rr}(3)$ \\
\hline Tili" torminalis & $\cdots$ & .. & $\cdots$ & $\cdots$ & vr (mixed woods only) (2). \\
\hline Tilia europaea & $\cdots$ & ... & ... & $\cdots$ & r-lf (? planted). \\
\hline Ulmus montana & $\ldots$ & ... & $\ldots$ & $\ldots$ & $\mathrm{r}-\mathrm{o}$. \\
\hline
\end{tabular}

Shrubs, etc.

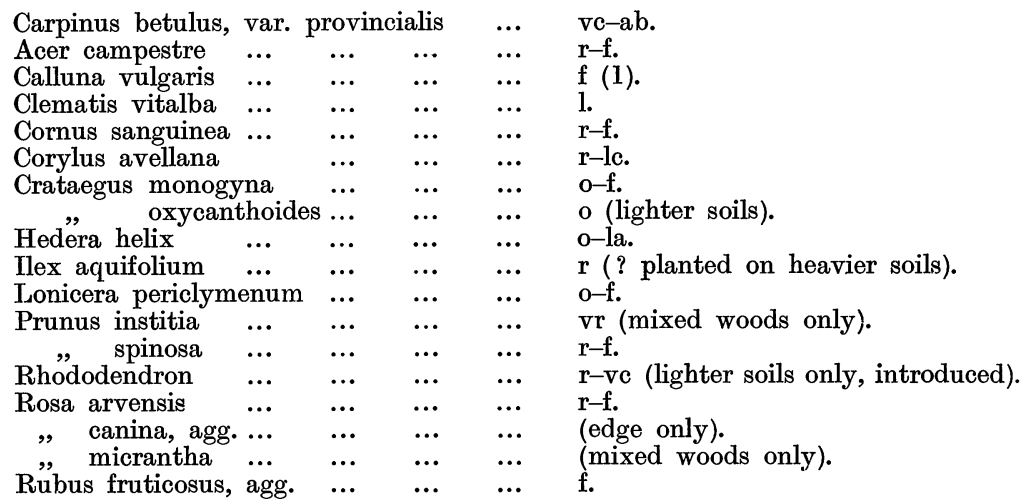

(The following forms have been recorded: R. affinis, R. leucostachys, R. lindleianus, R. radula, and R. rhamnifolius.)

$\begin{array}{llllll}\text { Rubus idaeus } & \ldots & \ldots & \ldots & \ldots & \text { vr-f (lighter soils). } \\ \text { Ruscus aculeatus } & \ldots & \ldots & \ldots & \ldots & \text { vr (1). } \\ \text { Salix aurita } & \ldots & \ldots & \ldots & \ldots & 1(3) . \\ \quad, \quad \text { caprea } & \ldots & \ldots & \ldots & \ldots & \text { r-f. } \\ \text { Sambucus nigra } & \ldots & \ldots & \ldots & \ldots & \text { f. } \\ \text { Solanum dulcamara } & \ldots & \ldots & \ldots & \text { r-lf. } \\ \text { Ulex europaeus } & \ldots & \ldots & \ldots & \ldots & \text { o-f (edge). } \\ \text { Viburnum opulus } & \ldots & \ldots & \ldots & \ldots & \text { (edge). } \\ \end{array}$

The symbols employed are as follows: ab, abundant; vc, very common; fc, fairly common; c, common; f, frequent; o, occasional; rr, rather rare; r, rare; vr, very rare; 1 , local. A number in brackets following a frequency indicates the number of woods from which a species has been recorded when not of general occurrence. 
(c) The Ground-flora. The character of the ground-flora is influenced very markedly by the nature of the upper layers of vegetation. Woods in which the standards are few, even where the shrub layer is dense, if regularly coppiced, generally exhibit an abundant spring-flora. On the other hand woods in which the standards are numerous, usually have a sparse herbaceous vegetation, except along the edges of the paths and rides and the margin of the wood. It has already been pointed out that this is probably mainly an effect of the diminished light (during the light-phase this may not be more than 37 per cent.) acting over a prolonged period, but it must be added that the light soils where a dense tree-layer usually obtains do not generally, under conditions of maximum illumination, bear so abundant a ground-flora as those of a heavier character. Occasionally however the two conditions of dense tree-layer and dense shrub-layer can be observed in different parts of the same wood, when the more abundant ground-flora in the latter case demonstrates the fact that light-intensity is the predominating factor.

We can recognise that the ground-vegetation is composed of several societies which appear to be chiefly related to differences in the degree of soil-moisture normally present. Each society is, under the appropriate edaphic conditions, quite distinctive, but just as there is every gradation from low to high water-content, so too there is every transition between the different societies, and consequently species that normally occur in the relation of dominant and subordinate may be present as co-dominants (Plate IX, Phot. 3).

Pteris Society. The driest society is that dominated by Pteris with which are usually associated Scilla, Holcus mollis, and Anemone, often however in very small amount. This society is but rarely encountered in the Quercus robur-Carpinus woods and then only on the lightest soils, usually occupied by the mixed woods of Quercus robur and Q. sessiliflora. Where the bracken covers any large area, there is often little undergrowth or the latter consists almost entirely of Rubus fruticosus (agg.) and Lonicera periclymenum.

Anemone Society. Next in order of increasing water-content is the Anemone society (Plate IX, Phot. 2), in which Conopodium and Scilla are often abundant species.

Mercurialis and Ficaria Societies. The damp parts of the wood are occupied by a society dominated either by Mercurialis or Ficaria (see Plate IX, Phots. 1 and 4). The two species are generally found in association, but their relative abundance varies greatly. Scilla nutans is often most abundant in the Mercurialis society.

The data given (Table XII) show that the water-content may be as high where Mercurialis perennis predominates as where Ficaria verna is the most abundant species, though in general the latter occupies the damper situations. The determining factor between the two appears to be light-intensity, the 
more deeply shaded areas being occupied by Ficaria, with which Arum maculatum is frequently associated. We have already noticed that Ficaria verna produces its foliage earlier than almost any other woodland species: The large part of the light-phase which is thus available for its assimilation probably renders the plant better able to withstand extreme shade-conditions. Estimations of water-content after spells of dry weather show that the difference in water-content between the different societies is under these conditions much less. Thus in Dowdell's Wood the water-content in the Anemone society was $29 \cdot 2$ per cent., whilst that of the Mercurialis society, on the same day, ranged from 30 to $32 \cdot 8$ per cent. It is in fact only after heavy rainfall that the soil of the damper societies receives the maximum amount of water it is capable of retaining. In connection with the occurrence of Mercurialis perennis and Ficaria verna in situations of high water-content it is interesting to note that Ficaria verna possesses well-developed hydathodes
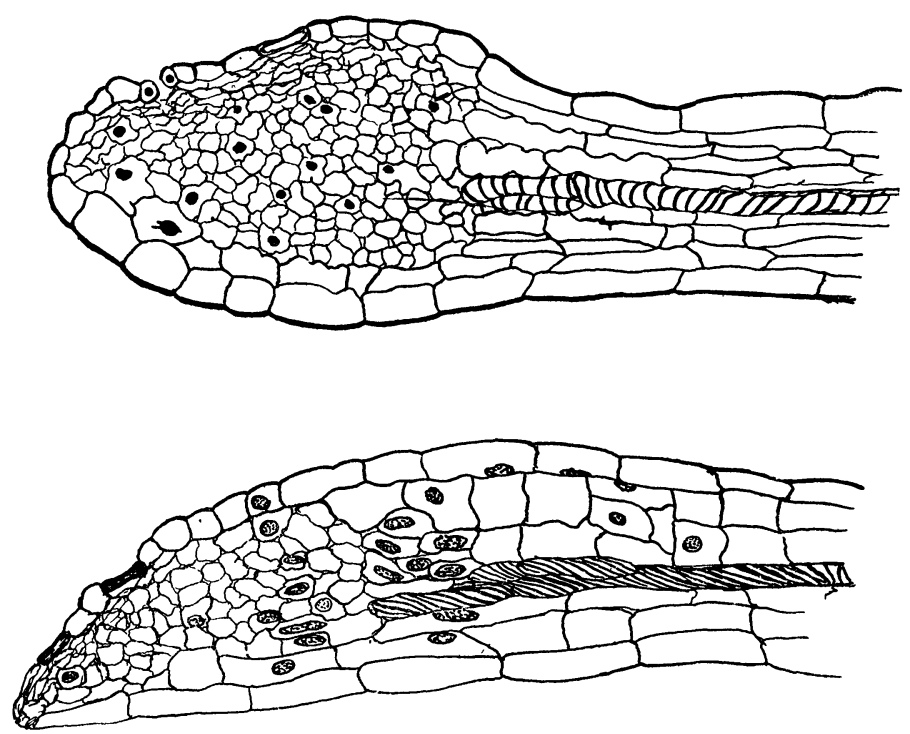

FIG. 11. Sections cut vertically through the leaf teeth of Ficaria verna (upper figure) and Adoxa moschatellina (lower figure) showing the hydathode in each case.

(Fig. 11), upon the margin of its leaves, which have been observed to actively secrete water under suitable conditions. The extrafloral nectaries of Mercurialis may also perform the same function. Ranunculus auricomus and Adoxa moschatellina (Fig. 11) which likewise possess efficient hydathodes are also particularly characteristic of the damper situations. From the estimations given (Tables XI and XII) it will be seen that the Mercurialis and Ficaria societies occupy the soil richest in humus, but the high water-content is often largely due to their frequently occupying situations at the base of slopes from which the drainage-water collects. 


\section{E. J. Salisbury}

The Mercurialis society also occurs in these woods on shallow soil where the water-content is low but where the acidity is low also, on account of the close proximity of the chalk. This type of Mercurialis society is often found associated with an undergrowth of Sambucus nigra or Corylus avellana. The acidity determinations in Table VI show that the acidity where Ficaria and Mercurialis predominate is low, whilst where Anemone predominates the acidity is high.

Permanently moist depressions are almost invariably occupied by a Ficaria society (Plate IX, Phot.4) accompanied or not by Mercurialis according to the light-intensity. In the wettest parts, subject to complete inundation in the winter-months Ficaria is accompanied or completely replaced by Ranunculus repens. The damp areas under trees forming a dense canopy and where there is no undergrowth are usually occupied by Mercurialis perennis (Plate IX, Phot. 1) and this species quite commonly forms patches beneath the canopy of isolated trees.

\section{Table XI. Organic Content of Soil in different Societies of the Ground-flora}

\begin{tabular}{|c|c|c|c|c|c|}
\hline \multicolumn{3}{|l|}{ Wood } & \multirow{2}{*}{$\begin{array}{c}\text { Character of vegetation } \\
\text { Pteris dom }\end{array}$} & \multicolumn{2}{|c|}{ Organic content $(\%)$} \\
\hline Hawkshead & $\cdots$ & $\cdots$ & & $7 \cdot 2$ & \\
\hline Oxhey ... & $\cdots$ & $\ldots$ & , & $9 \cdot 08$ & Av. $7 \cdot 21 \%$ \\
\hline Milwărd's & ... & $\ldots$ & & $5 \cdot 36$ & $5-9 \cdot 08 \%$ \\
\hline Hawkshead & ... & $\cdots$ & Anemone dom. & $8 \cdot 2$ & \\
\hline Oxhey & ... & $\ldots$ & , & $7 \cdot 4$ & \\
\hline Secret Spring & $\ldots$ & $\ldots$ & , & $8 \cdot 7$ & \\
\hline Well Wood (co & ppi & $\ldots$ & , & $8 \cdot 1$ & Av. $8 \cdot 5 \%$ \\
\hline Dowdell's & ... & $\ldots$ & , & $8 \cdot 36$ & Range, $7.4-10.7 \%$ \\
\hline Stocking's & $\ldots$ & $\ldots$ & , & $7 \cdot 48$ & \\
\hline Cutts Green & ... & $\ldots$ & , & $9 \cdot 4$ & \\
\hline Eight Acre & $\ldots$ & $\ldots$ & & $10 \cdot \overline{7}$ & \\
\hline Secret Spring & $\ldots$ & $\ldots$ & Anemone-Ścilla-Merc. & $11 \cdot 3$ & \\
\hline Marshall's & ... & $\ldots$ & , & $10 \cdot 8$ & Av. mixed, $11 \%$ \\
\hline Langley Wood & $\ldots$ & $\ldots$ & -Ficaria & $11 \cdot 0$ & \\
\hline Secret Spring & $\cdots$. & $\ldots$ & Ficaria dom. & $15 \cdot 44$ & \\
\hline Well Wood (co & ppi & $\ldots$ & „, & $11 \cdot 4$ & Av. $13 \cdot 8 \%$ \\
\hline Stocking's & $\cdots$ & $\ldots$ & , & $15 \cdot 52$ & Range, $11 \cdot 4-15 \cdot 2 \%$ \\
\hline Clapper's...: & ... & $\ldots$ & & $13 \cdot 1$ & \\
\hline Secret Spring & ... & $\ldots$ & Mercurialis vc & $11 \cdot 1$ & \\
\hline ", & $\cdots$ & $\cdots$ & $a b$ & $16 \cdot 8$ & \\
\hline , & $\cdots$ & $\cdots$ & $a b$ & $18 \cdot 3$ & \\
\hline Hawkshead & $\cdots$ & $\cdots$ & $\stackrel{\text { " }}{\mathrm{f}}$ & $9 \cdot 4$ & \\
\hline Oxhey $\ldots$ & $\begin{array}{l}\cdots \\
\ldots\end{array}$ & $\begin{array}{l}\cdots \\
\cdots\end{array}$ & $\begin{array}{l}\text { Mercurialis-Ficaria } \\
\text { Mercurialis dom. }\end{array}$ & $\begin{array}{r}11 \cdot 1 \\
5 \cdot 68\end{array}$ & Av. $11 \cdot 2 \%$ \\
\hline Mardley Heath & $\ldots$ & $\ldots$ & & $6 \cdot 08$ & Range, $5 \cdot 68-18 \cdot 72 \%$ \\
\hline Dowdell's & $\ldots$ & $\ldots$ & ," & $7 \cdot 2$ & \\
\hline Pryor's ... & $\ldots$ & $\ldots$ & ", & $8 \cdot 48$ & \\
\hline Milward's & $\ldots$ & $\ldots$ & ," & $11 \cdot 44$ & \\
\hline Stocking's & $\ldots$ & $\ldots$ & ", & $18 \cdot 72^{\prime}$ & \\
\hline
\end{tabular}

It may be noted that this situation is paralleled by the conditions in the average beech wood, where likewise there is a closed canopy and absence of undergrowth. In such a habitat the light-intensity during the shadephase is higher than where there is undergrowth, and the fact that Mercurialis and Pteris both retain their foliage during the shade-phase may explain their preference for this type of situation. 


\begin{tabular}{cccc}
\multicolumn{4}{c}{ Light-intensities } \\
Wuring & Shade-phase \\
Wood & Society & May & August \\
Langley & Anemone & $0.74 \%$ & $0.44 \%$ \\
Langley & Mercurialis & $1.17 \%$ & $0.76 \%$
\end{tabular}

The occurrence of Mercurialis in such abundance in these acid woods can be reconciled with its prevalence on dry calcareous soils if we regard acidity as the chief factor regulating its frequency. The acidity of the Mercurialis society, if relatively high, is counterbalanced by the high organic content which involves a high water-content. Where the Mercurialis society is associated with a low water-content, the acidity is low also. Thus the habitats probably agree in possessing, even in the dry season, a low concentration of the acids present.

\section{TABLE XII. Water-contents of Societies}

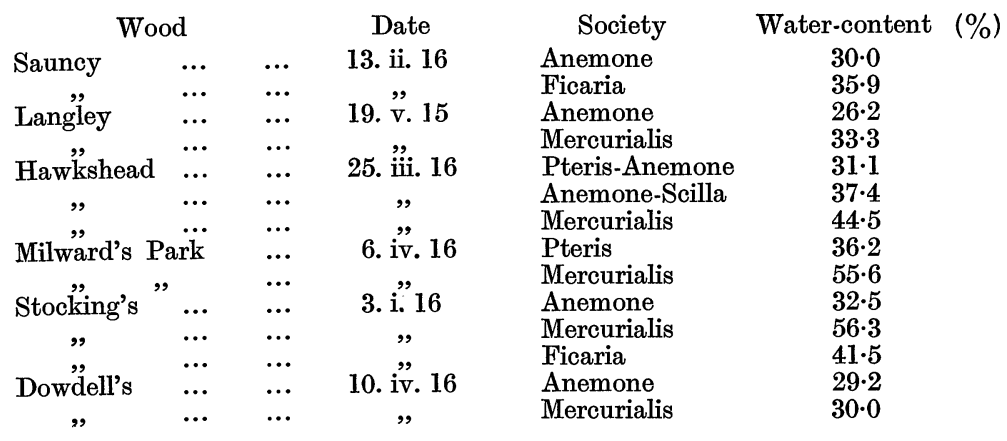

Rarely in the mixed oak woods the Ficaria of the Mercurialis-Ficaria society is replaced by Adoxa moschatellina, and it is interesting to note that in all the observed cases the associated undergrowth consisted of Corylus occupying relatively shallow soil resting on the chalk. These facts harmonise with the occurrence of this society in the oak-hazel woods of the county and its prevalence in the ash woods of Somerset ${ }^{1}$.

The shade-flora of the uncoppiced wood consists of few species, of which the most characteristic are Anemone nemorosa, Mercurialis perennis, Scilla nutans, Ficaria verna, Conopodium denudatum, Arum maculatum, Primula acaulis, and Galeobdolon luteum. In medium shade, not only are most of these species more vigorous, but in addition Ajuga reptans, Viola sylvestris, $V$. riviniana, and Veronica montana often become frequent. The remaining members of the shade-flora are either rare or confined to a few only of the woods. In the following lists the frequency symbols are intended as applying to the woods generally. Where a species is restricted to a few woods, the number in which it has been recorded is given in brackets.

1 See Moss, in Tansley's “Types of British Vegetation," 1911, p. 151. 


\section{TABLE XIII. List of Species in the Ground-flora}

Deep-shade flora.

\begin{tabular}{|c|c|c|c|c|}
\hline \multirow{3}{*}{$\begin{array}{l}\text { Adoxa moschatellina } \\
\text { Ajuga reptans } \\
\text { Anemone nemorosa }\end{array}$} & & $\cdots$ & & If $(2)$. \\
\hline & ... & ... & $\ldots$ & o (medium shade-f). \\
\hline & $\cdots$ & & $\ldots$ & vc-ab. \\
\hline , & var. $\mathrm{r}$ & robusta & $\cdots$ & $\operatorname{vr}(1)$ \\
\hline Arctium nemorosus & var. & apetala & ... & \\
\hline & $\cdots$ & $\cdots$ & $\cdots$ & r (medium shade $-r-f)$. \\
\hline $\begin{array}{l}\text { Arenaria trinerva } \\
\text { Arum maculatum }\end{array}$ & $\cdots$ & $\cdots$ & $\cdots$ & vr. \\
\hline & $\cdots$ & .. & ... & f-c. \\
\hline $\begin{array}{l}\text { Carex sylvatica } \\
\text { Conopodium denuda }\end{array}$ & $\cdots$ & $\cdots$ & $\cdots$ & vr. \\
\hline Epipactis latifolia & atum & $\cdots$ & $\cdots$ & $\begin{array}{l}f-v c . \\
\operatorname{vr}(1) .\end{array}$ \\
\hline , violacea & $\cdots$ & $\cdots$ & $\cdots$ & $\begin{array}{l}\text { vr (1). } \\
\text { rr (2). }\end{array}$ \\
\hline Ficaria verna... & $\ldots$ & $\ldots$ & $\cdots$ & c-ab. \\
\hline Galeobdolon luteum & incur & mbens & ... & $\operatorname{vr}(1)$ \\
\hline $\begin{array}{l}\text { Galeobdolon luteum } \\
\text { Geum urbanum }\end{array}$ & & $\cdots$ & $\ldots$ & f. \\
\hline $\begin{array}{l}\text { Geum } \\
\text { Hellebo }\end{array}$ & $\cdots$ & $\cdots$ & $\cdots$ & vn. \\
\hline $\begin{array}{l}\text { Hellebo } \\
\text { Heracle }\end{array}$ & $\dddot{0}$ & $\cdots$ & $\cdots$ & o-lf (4). \\
\hline $\begin{array}{l}\text { Heracle } \\
\text { Iris foe }\end{array}$ & lium & $\cdots$ & $\cdots$ & $\mathrm{vr}-\mathbf{r}$. \\
\hline $\begin{array}{l}\text { Iris toetidissima } \\
\text { Mercurialis perennis }\end{array}$ & $\cdots$ & $\cdots$ & $\cdots$ & $\mathrm{r}-\mathrm{vr}$ (chalk outcrops). \\
\hline Narcissus pseudo-na & urcissu & IS & $\cdots$ & $\begin{array}{l}a b-v c \\
f-v c(3)\end{array}$ \\
\hline Neottia nidus-avis & ... & $\cdots$ & ... & $\operatorname{vr}(3)$. \\
\hline Orchis mascula & $\cdots$ & ... & ... & lr-lf. \\
\hline Primula acaulis & $\cdots$ & $\cdots$ & $\ldots$ & f. \\
\hline $\begin{array}{l}\text { Ranunculus auricom } \\
\text { repens }\end{array}$ & us & $\cdots$ & $\cdots$ & r-fc (damper woods). \\
\hline $\begin{array}{l}\text { repens } \\
\text { ropaea }\end{array}$ & $\cdots$ & $\cdots$ & $\cdots$ & rr-lc (very damp places). \\
\hline $\begin{array}{l}\text { anicula } \\
\text { cilla nut }\end{array}$ & $\cdots$ & $\cdots$ & $\cdots$ & r. \\
\hline Viola riviniana & alba & $\begin{array}{l}\cdots \\
\cdots\end{array}$ & & $\begin{array}{l}\text { a. } \\
\mathrm{r}-\mathrm{vr}(5)\end{array}$ \\
\hline $\begin{array}{cc}\text { Viola riviniana } & \text { rivis } \\
,, & \text { sylvestris }\end{array}$ & $\cdots$ & $\cdots$ & $\cdots$ & vr (f in medium shade). \\
\hline " sylvestri & ... & “. & .. & $r-v r$ (f in medium shade). \\
\hline $\begin{array}{l}\text { Aspic } \\
\text { Athy }\end{array}$ & & & … & $\begin{array}{l}r-v r \text { ( } f \text { in medium shade, } \\
r-v r \text {. }\end{array}$ \\
\hline $\begin{array}{l}\text { Athyrium filix-foemi } \\
\text { teris aquilina }\end{array}$ & & & & vr. \\
\hline ris aquilina & $\cdots$ & ... & .. & $\mathrm{r}(\mathrm{ab}$ in 2$)$ \\
\hline
\end{tabular}

N.B. Of the above species, usually not more than about 12 are found in any one wood in the deep shade.

Additional species occurring in medium shade.

\begin{tabular}{|c|c|c|c|c|}
\hline Bryonia dioica & $\cdots$ & $\cdots$ & $\cdots$ & r. \\
\hline Galium aparine & $\cdots$ & $\ldots$ & $\cdots$ & r. \\
\hline Luzula pilosa & $\ldots$ & $\ldots$ & $\ldots$ & r. \\
\hline Nepeta glechoma & $\ldots$ & .. & $\cdots$ & rr. \\
\hline Rumex condylodes & $\ldots$ & $\ldots$ & ... & rr. \\
\hline Scrophularia nodosa & $a . .$. & $\cdots$ & $\cdots$ & r. \\
\hline Sedum telephium & $\cdots$ & $\cdots$ & $\cdots$ & $\operatorname{vr}(2)$. \\
\hline Urtica dioica & $\ldots$ & ... & ... & r. \\
\hline Veronica chamaedry & & $\cdots$ & $\cdots$ & r. \\
\hline montana & $\cdots$ & $\cdots$ & $\cdots$ & $r-f$. \\
\hline officinalis & $\ldots$ & $\ldots$ & $\ldots$ & r. \\
\hline
\end{tabular}

The following species have only been encountered in the ground-flora of woods where Quercus robur is accompanied by occasional trees of $Q$. sessitiflora, and, except where otherwise indicated, are of infrequent occurrence.

$\begin{array}{lllll}\text { Angelica sylvestris } & \ldots & \ldots & \ldots & \text { 1 (damper parts). } \\ \text { Aquilegia vulgaris } \ldots & \ldots & \ldots & \text { ? extinct. } \\ \text { Callitriche stagnalis } \ldots & \ldots & \ldots & \text { fc (rides, etc.). } \\ \text { Campanula latifolia } \ldots & \ldots & \ldots & \text { If (1). } \\ \text { ".. trachelium } & \ldots & \ldots & \text { If (1). } \\ \text { Carex" divulsa. }\end{array}$




\section{TABLE XIII (continued)}

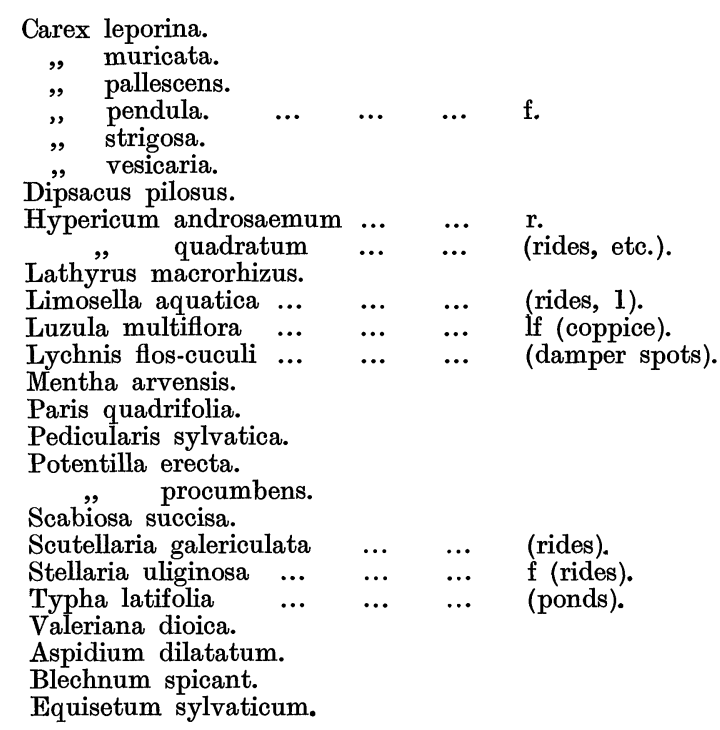

(d) Marginal and Path-floras. By far the greater part of the groundvegetation is to be found occupying the margin of the wood and the edges of the rides and paths. During the light-phase the intensity in these situations is seldom below 50 per cent. of the diffuse light outside and, even during the shade-phase, seldom falls below 5 per cent. whilst it is often over 20 per cent. As a consequence many plants which are relatively late in forming their vegetative organs and also flower late are able to occupy these situations. A complete list of the marginal and path-flora is given in Table XIV. Amongst the more characteristic members of the marginal society may be mentioned Agrostis alba, Ajuga reptans, Anthriscus sylvestris, Arenaria trinerva, Brachypodium sylvaticum, Bryonia dioica, Calamintha clinopodium, Chaerophyllum temulum, Galeobdolon luteum, Galium aparine, Geranium robertianum, Heracleum sphondylium, Holcus lanatus, Melica uniflora, Nepeta glechoma, Poa nemoralis, Potentilla fragariastrum, Rumex condylodes, Sanicula europaea, Sisymbrium alliaria, Stachys sylvestris, Stellaria graminea, S. holostea, Tamus communis, Torilis anthriscus, Veronica chamaedrys and Vicia sepium. Certain species appear to be confined to the actual paths themselves, possibly because these are often the dampest parts of the woods. None of these species is common, but Gnaphalium uliginosum, Lysimachia nemorum, Poa annua, Prunella vulgaris, Ranunculus repens and Veronica montana are especially characteristic of this situation.

The marginal flora has much in common with the flora of a hedgerow. Probably this is to be explained as due to the destruction of the primaeval forest which drove the species from the primitive scrub to seek sanctuary, 
more and more, along the margins of the surviving remnants of woodland and in the artificially constructed hedgerows. The more open parts bearing scrub would naturally be the first areas to pass into cultivation. It is therefore highly probable that the proportion of scrub to woodland at the present day is very much lower than it was in primitive times.

\section{TABLE XIV. Path and Marginal Species and Coppiced Flora}

\begin{tabular}{|c|c|c|c|c|c|c|c|c|c|}
\hline \multirow{3}{*}{\multicolumn{2}{|c|}{$\begin{array}{l}\qquad \text { Species } \\
\text { Aethusa cynapium ... } \\
\text { Agrimonia eupatorium }\end{array}$}} & \multicolumn{3}{|c|}{$\begin{array}{l}\text { Margin of woods } \\
\text { and rides }\end{array}$} & \multicolumn{3}{|c|}{ Path } & \multirow{2}{*}{\multicolumn{2}{|c|}{$\begin{array}{l}\text { Coppiced areas } \\
\operatorname{vr}(1) .\end{array}$}} \\
\hline & & $\ldots$ & - & $\ldots$ & $\cdots$ & - & $\ldots$ & & \\
\hline & & $\ldots$ & $\mathrm{r}$ & $\ldots$ & $\ldots$ & - & $\ldots$ & $\ldots$ & \\
\hline Agrostis alba ... & $\ldots$ & $\ldots$ & $\mathrm{f}$ & $\ldots$ & $\ldots$ & - & $\ldots$ & $\ldots$ & $f-v c$ \\
\hline " vulgaris & $\cdots$ & $\ldots$ & - & $\ldots$ & $\ldots$ & - & $\ldots$ & $\ldots$ & r. \\
\hline Aira caespitosa & $\cdots$ & $\cdots$ & $\mathrm{r}-\mathrm{f}$ & $\cdots$ & $\cdots$ & $\mathrm{r}-\mathbf{f}$ & $\cdots$ & $\cdots$ & - \\
\hline $\begin{array}{l}\text { Ä caryophyllea } \\
\text { Ajuga reptans }\end{array}$ & $\cdots$ & $\cdots$ & $\begin{array}{r}r \\
f\end{array}$ & $\cdots$ & $\cdots$ & - & $\cdots$ & $\cdots$ & E- \\
\hline $\begin{array}{l}\text { Ajuga reptans } \\
\text { Alchemilla arvensis }\end{array}$ & $\begin{array}{l}\ldots \\
\ldots\end{array}$ & $\cdots$ & f & $\cdots$ & $\cdots$ & $f$ & $\cdots$ & $\cdots$ & f-c. \\
\hline " pratensis & & $\cdots$ & $\mathrm{r}(1)$ & $\begin{array}{l}\cdots \\
\cdots\end{array}$ & $\cdots$ & c & $\because$ & $\begin{array}{l}\cdots \\
\cdots\end{array}$ & $\mathrm{r}(1)$. \\
\hline Anagallis arvensis & $\ldots$ & $\cdots$ & - & $\ldots$ & $\ldots$ & $\mathrm{r}$ & $\ldots$ & $\ldots$ & \\
\hline $\begin{array}{l}\text { Anthoxanthum odora } \\
\text { Anthriscus sylyestris }\end{array}$ & atum & $\ldots$ & - & $\cdots$ & $\cdots$ & - & $\cdots$ & $\cdots$ & $\mathrm{f}-\mathrm{vc}$. \\
\hline Anthriscus sylvestris & & $\cdots$ & $\mathrm{f}$ & $\cdots$ & $\cdots$ & - & $\cdots$ & $\cdots$ & f. \\
\hline Arctium nemorosus & & $\cdots$ & $o-f$ & $\cdots$ & $\cdots$ & - & $\cdots$ & $\cdots$ & o-f. \\
\hline $\begin{array}{c}\text { Arenaria leptoclados } \\
\text { trinerva }\end{array}$ & & $\cdots$ & - & $\cdots$ & $\cdots$ & - & $\cdots$ & $\cdots$ & r (1). \\
\hline $\begin{array}{l}\text { trinerva } \\
\text { Arrenatherum avena }\end{array}$ & $\ldots$ & $\cdots$ & $\mathrm{f}$ & $\cdots$ & $\cdots$ & - & $\cdots$ & $\cdots$ & $\mathrm{c}-\mathrm{vc}$ \\
\hline $\begin{array}{l}\text { Arrenatherum avena } \\
\text { Asperula odorata }\end{array}$ & $\begin{array}{l}\text { aceum } \\
\ldots\end{array}$ & $\begin{array}{l}\cdots \\
\cdots\end{array}$ & $\begin{array}{l}o \\
\text { rr-f }\end{array}$ & $\begin{array}{l}\cdots \\
\ldots\end{array}$ & $\cdots$ & 二 & $\cdots$ & $\cdots$ & o. \\
\hline $\begin{array}{l}\text { Asperula oodorata } \\
\text { Atriplex patula }\end{array}$ & $\ddot{\ldots}$ & $\cdots$ & - & $\cdots$ & $\cdots$ & 二 & $\cdots$ & $\cdots$ & $\overline{r .}$ \\
\hline Barbarea vulgaris & $\ldots$ & $\ldots$ & $\mathrm{r}$ & $\ldots$ & $\ldots$ & - & $\ldots$ & $\ldots$ & la. \\
\hline Brachypodium sylva & aticum & $\ldots$ & $\mathrm{f}$ & $\cdots$ & $\cdots$ & - & $\cdots$ & ... & - \\
\hline Brassica sinapastrum & & $\cdots$ & 一 & $\cdots$ & $\cdots$ & - & $\cdots$ & $\cdots$ & $\operatorname{vr}(1)$ \\
\hline Bromus asper & $\ldots$ & $\ldots$ & $\mathrm{rr}$ & $\ldots$ & $\ldots$ & - & $\ldots$ & ... & - \\
\hline Bryonia dioica & & $\ldots$ & f & $\ldots$ & $\ldots$ & - & $\ldots$ & $\ldots$ & - \\
\hline Calamintha clinopodi & lium & $\ldots$ & f & $\ldots$ & $\ldots$ & - & $\cdots$ & ... & \\
\hline Capsella bursa pasto & & $\ldots$ & - & $\cdots$ & $\cdots$ & - & ... & $\cdots$ & $r(1)$. \\
\hline Cardamine flexūosa & $\ldots$ & $\cdots$ & r (1) & $\ldots$ & $\ldots$ & - & $\ldots$ & $\ldots$ & - \\
\hline Carduus crispus & $\cdots$ & $\ldots$ & o (3) & $\ldots$ & $\ldots$ & - & $\ldots$ & ... & o (3). \\
\hline Carex binervis & $\ldots$ & $\ldots$ & $\mathrm{r}(1)$ & $\cdots$ & $\ldots$ & r (1) & $\ldots$ & $\ldots$ & - \\
\hline " sylvatica & $\cdots$ & $\cdots$ & $f-v \mathbf{r}$ & $\ldots$ & $\ldots$ & - & $\cdots$ & $\cdots$ & $o-f$. \\
\hline Centaurea pratensis & $\ldots$ & $\ldots$ & o & $\ldots$ & $\ldots$ & - & $\ldots$ & $\ldots$ & - \\
\hline Cerastium vulgatum & & $\ldots$ & $\mathrm{r}$ & $\ldots$ & $\ldots$ & - & $\ldots$ & $\ldots$ & o-r. \\
\hline Chaerophyllum temu & lum & $\ldots$ & $\mathrm{f}$ & $\ldots$ & $\ldots$ & - & $\ldots$ & $\ldots$ & o-f. \\
\hline Chenopodium album & & $\ldots$ & - & $\ldots$ & $\ldots$ & - & ... & ... & vr. \\
\hline " polyspe & ermum & & - & $\cdots$ & $\cdots$ & - & $\cdots$ & $\cdots$ & $f(1)$. \\
\hline $\begin{array}{l}\text { Chrysanthemum leuca } \\
\text { Circaea lutetiana }\end{array}$ & anthem & num & $\bar{r}$ & $\cdots$ & $\cdots$ & - & $\cdots$ & $\cdots$ & $\operatorname{vr}(1)$ \\
\hline Circaea lutetiana & $\cdots$ & $\cdots$ & $\begin{array}{r}r \\
r\end{array}$ & $\cdots$ & $\cdots$ & - & $\cdots$ & $\cdots$ & \\
\hline $\begin{array}{c}\text { Cnicus arvensis } \\
\text { lanceolatus }\end{array}$ & $\cdots$ & $\ldots$ & $\begin{array}{l}\mathbf{r}(2) \\
0-f\end{array}$ & $\begin{array}{l}\cdots \\
\ldots\end{array}$ & $\begin{array}{l}\ldots \\
\ldots\end{array}$ & 二 & $\begin{array}{l}\cdots \\
\ldots\end{array}$ & $\begin{array}{l}\cdots \\
\ldots\end{array}$ & $\begin{array}{l}\operatorname{vr} . \\
r-f .\end{array}$ \\
\hline $\begin{array}{l}\text { lanceolatus } \\
\text { palustris }\end{array}$ & $\cdots$ & $\cdots$ & 0 & $\ldots$ & $\ldots$ & - & $\ldots$ & $\ldots$ & $\mathrm{c}-\mathrm{vc}$. \\
\hline Crepis virens & $\ldots$ & $\ldots$ & - & $\cdots$ & $\cdots$ & - & $\cdots$ & $\ldots$ & r (2). \\
\hline Dactylis glomerata & ... & $\cdots$ & & $\cdots$ & $\cdots$ & - & $\cdots$ & $\cdots$ & 一 \\
\hline Digitalis purpurea & $\cdots$ & ... & $f(1)$ & $\ldots$ & $\ldots$ & - & $\ldots$ & $\ldots$ & - \\
\hline Dipsacus sylvestris & $\ldots$ & $\ldots$ & $\mathrm{r}$ & $\ldots$ & $\ldots$ & - & $\ldots$ & $\ldots$ & rr-lc. \\
\hline Epilobium angustifol & lium & ... & $\mathrm{r}$ & $\ldots$ & $\ldots$ & - & $\ldots$ & $\ldots$ & $\mathrm{r}-\mathrm{o}$ \\
\hline montanum & & $\cdots$ & $o-f$ & $\cdots$ & $\cdots$ & o & $\cdots$ & $\cdots$ & $o-f$. \\
\hline Ervthraea cetragonu & & $\cdots$ & 0 & $\cdots$ & $\cdots$ & $\mathrm{r}$ & $\cdots$ & $\cdots$ & \\
\hline $\begin{array}{l}\text { Erythraea centaureur } \\
\text { Euphorbia amygdalo }\end{array}$ & im & $\begin{array}{l}\cdots \\
\ldots\end{array}$ & $\overline{\mathrm{o}}$ & $\begin{array}{l}\cdots \\
\ldots\end{array}$ & $\begin{array}{l}\cdots \\
\ldots\end{array}$ & 二 & $\cdots$ & $\cdots$ & $\begin{array}{l}\text { t-c (lighter soils). } \\
\text { o. }\end{array}$ \\
\hline Lupnorora exigua & ... & $\cdots$ & - & $\cdots$ & & - & $\cdots$ & $\cdots$ & r. \\
\hline Fragaria vesca & $\cdots$ & $\cdots$ & $f-r$ & $\ldots$ & $\ldots$ & - & $\ldots$ & $\ldots$ & f. \\
\hline Fumaria officinalis & $\cdots$ & $\cdots$ & - & $\ldots$ & $\ldots$ & - & ... & $\cdots$ & r (1). \\
\hline Galeobdolon luteum & & $\cdots$ & $\mathrm{f}$ & $\cdots$ & $\cdots$ & - & $\cdots$ & $\cdots$ & o-vc. \\
\hline Galeopsis ladanum & $\cdots$ & $\cdots$ & $\overline{0}$ & $\cdots$ & $\begin{array}{l}\ldots \\
\ldots\end{array}$ & E & $\cdots$ & $\cdots$ & fe $(1)$. \\
\hline tetranit & $\cdots$ & $\cdots$ & 0 & $\cdots$ & $\cdots$ & - & $\cdots$ & $\cdots$ & $\mathrm{c}-\mathrm{vc}$ \\
\hline
\end{tabular}




\section{TABLE XIV (continued)}

Species

Galium aparine

" mollugo

, palustre

, saxatile

Geranium columbinum

, dissectum ...

", molle

robertianum

Geum urbanum

Gnaphalium sylvaticum uliginosum

Heracleum sphondylium Hieraceum boreale ...

Holcus lanatus

Hypericum humifusum

$$
\text { , perforatum }
$$$$
\text { pulchrum }
$$

Hypochaeris radicata

Juncus effusus

supinus $\quad \cdots$

Lactuca muralis

Lapsana communis ...

Lathyrus nissolia

" pratensis ...

Listera ovata

Lolium perenne

Luzula multiflora ...

, pilosa

Lychnis dioica

"Lysimachia nemorum

Malva moschata $\begin{array}{ll}\text { moschata } & \ldots \\ \text { sylvestris } & \text {.. }\end{array}$

Matricaria inodora ...

Melica uniflora

Melilotus officinalis ...

Milium effusum

Myosotis arvensis

Nepeta glechoma

Orchis maculata

Oxalis acetosella

Papaver rhoeas

Peplis portula

Picris echioides

Pimpinella major

Plantago lanceolata ...

Poa " major ...

" nemoralis

", trivialis

Polygonum aviculare

, convolvulus " $\quad$ lapathifolium Potentilla $\begin{gathered}\text { persicaria } \\ \text { fragariastrum }\end{gathered}$

Prunella vulgaris

Ranunculus repens $\ldots$

Rumex acetosa
Margin of woods

$$
\text { and rides }
$$

$\begin{array}{ll}\ldots & \mathbf{f} \\ \ldots & \text { o }\end{array}$

$\begin{array}{ll}\cdots & \\ \cdots & -\end{array}$

$\cdots \quad-$

...

...

$\begin{array}{llll}\cdots & \text { o-f } & \cdots & \cdots \\ \cdots & \text { r-f } & \cdots & .\end{array}$

$\begin{array}{lll}\cdots & - & \\ \cdots & - & \cdots\end{array}$

... f $-\mathrm{c}$

... $\quad$ o (light soil)

... 0

$\ldots \quad$ f $\ldots$ (light soil) $\ldots$

... $-\quad \ldots \quad$..

$\begin{array}{ll}\ldots & \mathbf{f}-\mathrm{r} \quad \ldots \\ \ldots & \mathrm{r}-\mathrm{vr} \text { (light soil) }\end{array}$

$\cdots$

$\ldots$

..

$\begin{array}{lll}\ldots & 0\end{array}$

‥ $\quad$ -

...

$\ldots \quad$ r (heavy soils)

$\begin{array}{llll}\cdots & r & \cdots & \cdots\end{array}$

$\begin{array}{llll}\ldots & \text { r } & \ldots & \ldots \\ \ldots & \text { vr } & \ldots & .\end{array}$

$\begin{array}{lll}\ldots & \text { vr } & \ldots \\ \ldots & \text { vr } & \ldots \\ \ldots & - & \ldots\end{array}$

$\begin{array}{lll}\ldots & - & \ldots \\ \cdots & \mathbf{r} & \ldots \\ \cdots & \mathrm{c}-\mathbf{f} & \cdots\end{array}$

$\begin{array}{llll}\ldots & - & \ldots & \ldots \\ \ldots & 0 & \ldots & \ldots\end{array}$

$\cdots$

...

$\cdots$

$\cdots$

...

$\cdots$

...

$\cdots$

$\cdots$

...

f

$\cdots \quad \begin{array}{llll}\cdots & 0 & \ldots & \\ \cdots & \end{array}$

$\cdots=\cdots \cdots=$

$\ldots$

$\ldots$

$\ldots$ f

$\cdots=\cdots$

$\cdots=\cdots{ }^{\mathrm{rr}-\mathrm{f}}$

$\ldots=\ldots$ $\ldots$

Path $\begin{array}{lll}- & \cdots & \ldots\end{array}$

f (1) (light soils)

․ $\quad \cdots \quad$ o $(2)$

f-c.

r (1).

r.

r-f.

f (1) (light soil).

f-c.

c-ab.

$\mathrm{r}-\mathrm{ve}$.

$r$.

f-r.

r.

r-lc.

二

r.

二

o.

vr (1).

1 (lighter soils).

o-f.

r-f.

r.

r-f.

vr.

vr.

r (1).

f-ve.

f (2).

rr-c.

f-c.

o-fc.

c.

vr (1).

lr (3).

r (3).

f (1).

r-f.

f-c.

o.

r-f.

o-f (4).

f-c (2).

o-f (2)

c-r'.

rr.

r.

r (1).

r-f (3) (light soils). 


\section{TABLE XIV (continued)}

\begin{tabular}{|c|c|c|c|c|c|c|c|c|c|}
\hline Species & & Mar & $\begin{array}{l}\text { of wo } \\
\text { rides }\end{array}$ & oods & & Path & & & Coppiced areas \\
\hline Rumex condylodes & ... & $\cdots$ & f & ... & $\cdots$ & - & $\ldots$ & $\cdots$ & f-lc. \\
\hline crispus & ... & $\ldots$ & $\mathrm{r}$ & ... & ... & - & ... & ... & r. \\
\hline obtusifolius & $\ldots$ & $\ldots$ & o & ... & ... & - & $\ldots$ & $\cdots$ & lf. \\
\hline Sagina procumbens & ... & $\ldots$ & - & ... & $\cdots$ & r (2) & ... & ... & - \\
\hline Sanicula europaea & $\ldots$ & $\ldots$ & $f-v c$ & ... & $\ldots$ & 一 & $\cdots$ & $\cdots$ & $\mathrm{f}-\mathrm{vc}$ \\
\hline Scleranthus annuus & $\ldots$ & $\ldots$ & - & ... & ... & r (2) & ... & ... & r (2). \\
\hline Scrophularia nodosa & $\ldots$ & $\ldots$ & o-f & ... & ... & - & ... & $\ldots$ & o-f. \\
\hline Senecia jacobaea & ... & $\ldots$ & 一 & ... & ... & - & ... & $\ldots$ & r (1). \\
\hline " sylvaticus & $\cdots$ & $\cdots$ & $\mathbf{r}$ & $\cdots$ & $\cdots$ & 一 & $\cdots$ & ... & r. \\
\hline vulgaris & ... & $\ldots$ & 一 & $\ldots$ & $\ldots$ & - & $\ldots$ & $\ldots$ & r. \\
\hline Sherardia arvensis & $\ldots$ & $\ldots$ & - & $\ldots$ & $\ldots$ & - & $\ldots$ & ... & r (1). \\
\hline Silene inflata & $\ldots$ & $\ldots$ & $r-f$ & $\ldots$ & ... & - & $\ldots$ & $\ldots$ & r-f. \\
\hline Sisymbrium alliaria & ... & $\ldots$ & $\mathrm{f}-\mathrm{c}$ & $\ldots$ & ... & - & $\ldots$ & $\ldots$ & f. \\
\hline , $\quad$ thalianu & um & $\ldots$ & - & $\cdots$ & $\ldots$ & - & $\ldots$ & $\ldots$ & r (1). \\
\hline Solanum nigrum & $\ldots$ & $\ldots$ & 一 & $\ldots$ & $\ldots$ & - & $\ldots$ & $\ldots$ & f $(1)$. \\
\hline Solidago virgaurea & ... & $\ldots$ & r (2) & (lighter & soils) & - & ... & $\ldots$ & $r(2)$. \\
\hline Sonchus asper & ... & $\ldots$ & 一 & ... & ... & - & ... & $\ldots$ & $\mathrm{r}-\mathrm{f}(4)$ \\
\hline " oleraceus & ... & $\ldots$ & 一 & ... & ... & - & $\ldots$ & ... & vr (3). \\
\hline Spergula arvensis & ... & $\ldots$ & - & ... & ... & - & ... & ... & ve (1). \\
\hline Stachys betonica & $\ldots$ & $\ldots$ & r (2) & ... & ... & - & $\ldots$ & ... & - \\
\hline , sylvatica & ... & $\ldots$ & $f$ & ... & ... & 一 & ... & ... & f-c. \\
\hline Stellaria graminea & ... & $\ldots$ & f & ... & $\ldots$ & - & ... & $\ldots$ & f-c. \\
\hline ", holostea & ... & $\ldots$ & f & ... & ... & - & ... & ... & f-vc. \\
\hline,$\quad$ media & ... & $\cdots$ & - & ... & $\cdots$ & - & $\cdots$ & $\cdots$ & r. \\
\hline Tamus communis & $\ldots$ & $\ldots$ & f & ... & $\cdots$ & - & $\cdots$ & $\cdots$ & r. \\
\hline Taraxacum officinalis & & $\ldots$ & - & $\ldots$ & $\ldots$ & - & $\cdots$ & $\cdots$ & r (3). \\
\hline Teucrium scorodonia & & $\ldots$ & f (ligh & hter soil & & - & $\ldots$ & $\cdots$ & f-c. \\
\hline Torilis anthriscus & ... & $\ldots$ & f & ... & $\cdots$ & - & ... & $\cdots$ & f. \\
\hline Trifolium repens & ... & $\ldots$ & 一 & ... & ... & $\mathrm{r}$ & ... & ... & - \\
\hline Triticum caninum & $\ldots$ & $\ldots$ & o (2) & & ... & - & ... & $\ldots$ & - \\
\hline , repens & ... & $\ldots$ & $\mathbf{r}$ & $\cdots$ & ... & 一 & ... & $\ldots$ & 一 \\
\hline Urtica dioica & $\ldots$ & $\ldots$ & $\mathbf{r}$ & ... & ... & - & $\ldots$ & $\ldots$ & $r-f$. \\
\hline Verbascum thapsus & ... & $\ldots$ & $\mathbf{r}$ & ... & ... & - & ... & $\ldots$ & lf-rr. \\
\hline Veronica agrestis & ... & $\ldots$ & - & ... & $\cdots$ & - & $\cdots$ & $\cdots$ & r. \\
\hline arvensis & ... & $\cdots$ & - & $\cdots$ & ... & - & $\cdots$ & $\cdots$ & r. \\
\hline buxbaumii & ... & $\ldots$ & 一 & ... & ... & - & ... & ... & r. \\
\hline chamaedrys & & $\ldots$ & $\mathrm{c}$ & $\ldots$ & $\ldots$ & - & $\ldots$ & $\ldots$ & $f-c$. \\
\hline montana & $\ldots$ & $\ldots$ & 一 & ... & ... & $\mathrm{r}-\mathbf{f}$ & ... & ... & $\mathbf{r}-\mathbf{c}$. \\
\hline officinalis & ... & $\ldots$ & 一 & $\ldots$ & $\ldots$ & $\mathbf{r}$ & $\cdots$ & $\ldots$ & r. \\
\hline serpyllifolia & & $\ldots$ & - & $\ldots$ & $\ldots$ & $\mathbf{r}$ & $\ldots$ & $\ldots$ & r. \\
\hline Vicia angustifolia & ... & $\ldots$ & $\mathbf{r}$ & ... & ... & - & ... & ... & r. \\
\hline ,, hirsuta & $\cdots$ & $\ldots$ & $\mathbf{r}$ & ... & $\cdots$ & - & $\cdots$ & ... & r. \\
\hline " sativa & ... & $\ldots$ & - & ... & ... & - & ... & ... & rr (1). \\
\hline , sepium & ... & $\ldots$ & f & $\cdots$ & ... & - & $\cdots$ & $\cdots$ & rr. \\
\hline Viola arvensis & ... & $\ldots$ & - & $\cdots$ & $\cdots$ & - & $\cdots$ & $\cdots$ & r-rr. \\
\hline " riviniana & $\cdots$ & $\cdots$ & $\mathbf{r}-\mathbf{f}$ & $\cdots$ & $\cdots$ & 一 & $\cdots$ & $\cdots$ & $\mathrm{c}-\mathrm{vc}$ \\
\hline „ sylvestris var. & pun & ata & f & $\ldots$ & ... & - & $\cdots$ & $\ldots$ & c. \\
\hline
\end{tabular}

The following species occur in these woods, but are rare and restricted to local outcrops of chalk: Carex glauca, Cephalanthera pallens, Daphne laureola, Habenaria chlorantha, Ophrys muscifera, and Viola hirta.

(e) Competition. Competition between the species growing together may be the result of a struggle between the root-systems, between the aerial organs, or both. Species can only grow together without competition where their demands upon the soil are different or their roots are situated at different depths and their aerial organs are produced at different times of the year. 
A study of the data given (Tables XV and XVI) shows that Adoxa moschatellina, Anemone nemorosa and Ficaria verna, all have roots situated at about the same level in the soil, and there is similarly competition between their aerial organs. We have already seen that these are species which tend to replace one another rather than to grow together. Adoxa and Ficaria are frequently found in association with Mercurialis and this is in harmony with the fact that the root-systems of the two former are at a different level from those of the last; both can moreover endure considerable shade. Anemone and Conopodium, which frequently occur together, produce most of their roots at different levels and the same is true with reference to Mercurialis perennis and Scilla nutans.

Table XV. Average Rooting Depths of Woodland Species

\begin{tabular}{llll}
\multicolumn{1}{c}{ Species } & & Rooting depths \\
Adoxa moschatellina & $\ldots$ & $1-3$ inches \\
Ficaria verna & $\ldots$ & $\ldots$ & $1-3$ \\
Anemone nemorosa & $\ldots$ & $\ldots$ & $2-3$ \\
Holcus lanatus & $\ldots$ & $\ldots$ & 3 \\
Ranunculus auricomis & $\ldots$ & 3 \\
Mercurialis perennis & $\ldots$ & $3-4$ \\
Orchis mascula & $\ldots$ & $\ldots$ & $3 \frac{1}{2}-4$ \\
Arenaria trinerva & $\ldots$ & $\ldots$ & 4 \\
Primula acaulis & $\ldots$ & $\ldots$ & 4 \\
Sanicula europaea & $\ldots$ & $\ldots$ & 4 \\
Viola sylvestris & $\ldots$ & $\ldots$ & 4 \\
Galeobdolon luteum & $\ldots$ & $4-5$ \\
Conopodium denudatum & $\ldots$ & $3-6$ \\
Scilla nutans & $\ldots$ & $\ldots$ & $4-6$ \\
Arum maculatum & $\ldots$ & $\ldots$ & $7-8$ \\
Pteris aquilina & $\ldots$ & $\ldots$ & $6-10$ \\
Rumex condylodes & $\ldots$ & $\ldots$ & 9 \\
Anthriscus sylvestris & $\ldots$ & 9 \\
Heracleum sphondylium & $\ldots$ & 12 \\
Arctium nemorosum & $\ldots$ & 18 \\
Bryonia dioica & $\ldots$ & $\ldots$ & 18 \\
Tamus communis & $\ldots$ & $\ldots$ & $18-24$
\end{tabular}

Table XVI. Average Heights of Aerial Shoots in May

\begin{tabular}{llll}
\multicolumn{1}{c}{ Species } & \multicolumn{2}{c}{ Height of shoot } \\
Adoxa moschatellina & $\ldots$ & $1-2$ inches \\
Ficaria verna & $\ldots$ & $\ldots$ & $2-3$ \\
Anemone nemorosa & $\ldots$ & $\ldots$ & $5-6$ \\
Primula acaulis & $\ldots$ & $\ldots$ & $4-5$ \\
Conopodium denudatum & $\ldots$ & 6 \\
Galeobdolon luteum & $\ldots$ & $7-8$ \\
Mercurialis perennis & $\ldots$ & $7-9$ \\
Arum maculatum & $\ldots$ & $\ldots$ & $6-10$ \\
Scilla nutans & $\ldots$ & $\ldots$ & 8
\end{tabular}

(f) The Cryptogamic Flora. The cryptogamic flora in these woods has not been completely worked out, but appears to be distinctly poor compared with that of the Quercus sessiliflora-Carpinus woods in the same area. The Fungi are under investigation at the hands of Mr J. Ramsbottom, M.A., so 
that no list is here given. Of the Mosses the following are often common: Brachythecium rutabulum, Catharinea undulata, Dicranella heteromella, Eurhynchium rusciforme often abundant on damp places, Hypnum cupressiforme, Mnium hornum, $M$. undulatum and Thamnidium tamariscifolium. Other frequent species are Aulacomnium androgynum, Dicranum scoparium, Eurhynchium piliferum, Hypnum purum, H. squarrosum (paths), Polytrichum formosum and Rynchostegium confertum. Very few Liverworts have been noted, and of these the commonest are Lophocolea bidentata, Madotheca platyphylla, Metzgeria furcata, Radula complanata, and, on the lighter soils only, Pellia epiphylla. Parmelia caperata, $P$. perlata and $P$. physodes are the only common Lichens and the paucity of this section of the Cryptogamic flora is in marked contrast to that of the Quercus sessiliflora-Carpinus woods.

The only common Algae appear to be Hormidium flaccidum upon the bare patches of ground and Chlorella sp. and Pleurococcus sp. upon the tree-trunks.

(g) Exposure. Quite apart from the decreased intensity of the light the shade-phase is also characterised by the increase of shelter afforded to the ground-flora. The early production of foliage by woodland species involves their subjection to a very wide range of conditions affecting transpiration. The exposure is naturally greatest in the earlier months of the year, when the shelter is at a minimum. As the herbs begin to grow, however, they afford themselves mutual protection. Two features, both commonly exhibited by woodland species, tend to reduce the effect of the pre-vernal exposure. The first and most important of these is the social habit. For the shoots of any one species naturally tend to grow at approximately the same rate and to the same height. Moreover the tendency to produce their foliage horizontally at one level, an outcome of the mosaic-tendency seen in its extreme form in Anemone and Adoxa, results in a maximum of shelter. As a consequence of this each species creates its own shelter. Thus estimations of the evaporation in an uncoppiced wood showed that evaporation was 3 to 4 times as rapid above the level of the social species as in the shelter of Anemone nemorosa and Mercurialis perennis.

The second feature which tends to check excessive transpiration is the hairiness of the young leaves of many species, e.g. Anemone nemorosa, Mercurialis perennis, Primula acaulis, Galeobdolon luteum, Potentilla fragariastrum, Veronica chamaedrys and Nepeta glechoma. The glabrous-leaved social species, such as Adoxa moschatellina and Ficaria verna, not only inhabit the damper situations, but owing to their low growth bear their leaves in the relatively humid layer near the ground.

As the leaves of the hairy-leaved species expand, which they do but slowly, the increased rate of transpiration more or less keeps pace with the decreasing exposure. Moreover as regards internal structure the later foliage bears much the same relation to that first formed as do shade-leaves to sun-leaves. 


\section{(5) The Flora of the Coppiced Wood.}

(a) The Character of the Coppice-flora. In most of the woods with which we are dealing the shrub layer is coppiced at more or less regular intervals. Walker in his General View of the Agriculture of Hertford (London, 1795) refers to its well-wooded character and states (p. 69) that "the woods are cut in succession every ten years." In a subsequent edition of the same work published in 1804 Walker mentions that the woods between Hockerill, Ware, and Buntingford are cut every twelve years when in the landlord's hands, but that tenants cut them every nine or ten years, so as to obtain the advantage of two crops in the 21 years' lease. So far as the writer's experience goes, however, many of the woods are often allowed to grow for a period of 14 to 16 years or sometimes even 20 years. By the term coppicing is implied the cutting down of the shrub layer only, though in its loose and incorrect appellation the term is sometimes employed to connote partial felling of the trees also. The two processes in practice often take place in succession, the standards being usually felled in April or May, following upon the coppicing which is carried out from January to March.

Whereas the coppicing period is relatively short the standards are only felled after 80 to 150 years, so that we must be careful to distinguish between these two causes in their separate effects.

In most of these woods the standards are too far apart to produce any very marked shading effect during the light-phase. When the leaves develop however the shading effect of the standards is pronounced. In a coppiced wood the intensity of the diffuse light during the shade-phase is usually between 20 per cent. and 40 per cent., but may be as low as 10 per cent., the differences depending upon the number of standards per acre. Where the intensity is under 10 per cent. there is no appreciable increase in the number of species as the result of coppicing, the only effect being an augmentation of the shade-flora. In such woods it is only after felling that the groundflora exhibits the marked and rapid development which usually accompanies a cutting down of the shrub layer. The most important effect of coppicing is a greatly increased illumination and this is manifested by the vegetation in two ways. Firstly, there is a great addition to the number of species occupying the areas formerly shaded (compare Plate X, Phots. 6, 7); secondly, the species already present exhibit an increase both in the number and vigour of the individuals. A study of the lists given in Table XVI shows that the flora of a coppiced area is made up of three parts, viz. $(a)$ the original shadeflora; (b) species formerly occupying the margins of the wood and rides; and $(c)$ weeds. Out of 129 species recorded in the ground-flora of coppiced areas, 79 or 61.2 per cent. belong to the second category, and 38 or $29 \cdot 4$ per cent. are weeds characterised by the facility of their dispersal. The coppiceflora therefore tends to be abundant where the coppice-area is (1) near the 
edge of the wood, (2) bordered or intersected by paths, (3) in close proximity to another area recently coppiced (see Table XVIII, $d$ and $e$ ), (4) adjacent to cultivated ground.

Amongst the commonest species during the first season after coppicing may be mentioned Cnicus palustris (Plate X, Phot. 7), Holcus lanatus (with H. mollis on lighter soils), Galeopsis tetrahit, and Anthoxanthum odoratum. Other characteristic species frequent or common in the first or second year are Melampyrum pratense, Agrostis alba, Erythraea centaurea, Epilobium montanum, Heracleum sphondylium, Geranium dissectum, Barbarea vulgaris, Stachys sylvatica, Fragaria vesca, Stellaria holostea, S. graminea and Poa nemoralis. Species which pass the winter in the rosette-condition are frequent and include Cnicus palustris, Dipsacus sylvestris, Geranium dissectum, Barbarea vulgaris and Verbascum thapsus. The abundance of Cnicus palustris is illustrated by a count of the plants of this species made in a wood six months after coppicing which showed no less than 23 individuals per square foot. The maximum development of the ground-flora is usually reached in the second or third year after coppicing. Several species that were relatively subordinate in the uncoppiced state increase appreciably in amount (see Table XVII). This is very pronounced in the case of Ajuga reptans, Arenaria trinerva, Geum urbanum, Galeobdolon luteum, Nepeta glechoma, Sanicula europaea, Veronica chamaedrys and Viola spp.

\section{Table XVII. Effect of Coppicing on Frequency in Interior of Wood}

\begin{tabular}{|c|c|c|c|c|c|c|}
\hline \multirow{2}{*}{\multicolumn{2}{|c|}{ Species }} & \multirow[b]{2}{*}{ Before coppicing } & \multicolumn{4}{|c|}{ After coppicing } \\
\hline & & & 1st yr. & 2nd yr. & 3rd yr. & 4th $\mathrm{y}$ \\
\hline ptans & $\ldots$ & f & f & c & fc & f. \\
\hline Arenaria trinerva $\ldots$ & $\ldots$ & vr & c & fe & o & f. \\
\hline Cnicus palustris $\ldots$ & $\ldots$ & absent & $f$ & $\mathrm{c}-\mathrm{vc}$ & fc-c & \\
\hline Galeopsis tetrahit ... & $\ldots$ & absent & $c-v e$ & $0-\mathbf{r}$ & 0 & abs. \\
\hline Veronica chamaedrys & $\ldots$ & $\mathbf{r}$ & $\mathrm{o}-\mathrm{c}$ & $f-c$ & fc-r $r$ & r. \\
\hline
\end{tabular}

The influx of photophilous species during the first two years is illustrated by Table XVIII. As a consequence of their presence the shade-flora becomes correspondingly reduced.

TABLE XVIII. Number of Species occupying the Interior of various Woods

\begin{tabular}{llllccc}
\multicolumn{2}{c}{} & & & & \multicolumn{2}{c}{ After coppicing } \\
\multicolumn{1}{c}{ Wood } & & & Before coppicing & 1st yr. & 2nd yr. \\
(a) & Pismire & $\ldots$ & $\ldots$ & 9 & 25 & 51 \\
(b) & Clapper's & $\ldots$ & $\ldots$ & 10 & 35 & 63 \\
(c) & Stocking's & $\ldots$ & $\ldots$ & 10 & 28 & 65 \\
(d) & Well Wood* & & $\ldots$ & 11 & 58 & \\
(e) & Stocking's* & $\ldots$ & $\ldots$ & 10 & 69
\end{tabular}

* The coppiced areas in these two cases were adjacent to other recently coppiced areas, hence the large number of species in the first year.

The number of species in the coppiced wood increases for several years owing to the dependence of dispersal upon the time-factor. This is illustrated 
by the case of Eight Acre Wood in which 34 species were present in the third year, whilst five years after coppicing the number had risen to 61 . But though the number of species increases there is a decrease in the number of individuals, as the pressure of competition becomes greater. For, as the shade cast by the growing stools becomes more and more pronounced, the area occupied by the photophilous species gets gradually restricted. As a result the light-demanding species become forced further and further from the stools and thus the light-flora constitutes a sort of irregular reticulum, the meshes of which are occupied by the sprouting stools surrounded by members of the shade-enduring species. This is clearly brought out by a study of the species in coppiced woods after several years have elapsed. For example, in Cutts Green Wood out of a total of 50 herbaceous phanerogamic species present in the third year, 40 of the species were only to be found in the lighter areas where the bushes had not yet formed a closed canopy. In a second example in the fifth year after coppicing, of the 56 species 14 only were beneath the shade of the bushes. In a third wood, coppiced seven years previously, 33 out of the 46 species present were restricted to the areas beneath the interstices of the canopy. Ultimately the lightdemanding species become confined, as before coppicing, to the sides of the paths and the edges of the wood.

(b) Acidity. I am indebted to Dr H. B. Hutchinson for estimating the soil-acidity of composite samples from coppiced and uncoppiced areas. These estimations show that the average acidity of the coppiced wood is, during the first two years, higher than that of the uncoppiced. The average acidity of the soil in the uncoppiced wood is about 0.44 per cent. whilst of the coppiced it is about 0.46 per cent. The increased acidity is doubtless due to breakdown of some of the organic matter present, since the average humus-content in the uncoppiced condition is $12 \cdot 6$ per cent. whereas in the coppiced it is only $10 \cdot 4$ per cent.

Such a decrease in humus-content entails of course a corresponding decrease in the water-content and hence greater concentration of the acids present.

It is probably in part owing to the relatively high acidity of such woods immediately after coppicing that we find Holcus lanatus, Cnicus palustris and Anthoxanthum odoratum, all three species characteristically tolerant of high acidities, in such abundance during the first few years. In the second or third year the acidity begins to fall and these species decrease in abundance.

(c) Other Effects of Coppicing. Several of the species that in the uncoppiced wood will grow in deep shade do not flower under this condition, but blossom profusely in the first year after coppicing. This is notably the case with such species as Ajuga reptans, Galeobdolon luteum, Nepeta glechoma, Conopodium denudatum and Geum urbanum. As already mentioned the effect in this respect is most marked upon the later-flowering species. 
The increased exposure due to coppicing is expressed in the vegetation by the large number of rosette-plants already referred to. The rate of evaporation in a coppiced area may, even in the light-phase, be from 5 to 15 times that in the uncoppiced condition. The vernal species, in the first year after coppicing, often present a stunted appearance and the vigour of the vegetation in the second and third years is probably in part due to the effective shelter furnished by the sprouting stools. Probably too the power of these rosette species to kill off surrounding vegetation is in part responsible for their success.

(d) Effect of Coppicing on Soil-temperature. In order to obtain some idea of the effect of coppicing on the soil-temperature gradient in spring estimations were made with ordinary mercurial thermometers placed with their bulbs at the depth of maximum root-development, viz. 6 inches. .To avoid any effect from direct sunlight the projecting tube was in every case covered. The temperatures were taken simultaneously in six different spots in the uncoppiced wood, and six others in the coppiced part. For purposes of comparison the average of each set has been taken. It will be seen from the accompanying table (XIX) that the temperature of the soil at this depth

\begin{tabular}{|c|c|c|c|c|}
\hline Date & & $\begin{array}{c}\text { Mean temperature } \\
\left({ }^{\circ} \mathrm{C} \text {.) of air between }\right. \\
\text { successive observations }\end{array}$ & $\begin{array}{l}\text { Average temperature } \\
{ }^{\circ} \mathrm{g} \text {.) of soil in } \\
\text { coppiced part of wood }\end{array}$ & $\begin{array}{l}\text { Average temperature } \\
\text { ( } \mathrm{C} \text {.) of soil in } \\
\text { uncoppiced part }\end{array}$ \\
\hline March & 3 & & $3 \cdot 3$ & $3 \cdot 7^{1}$ \\
\hline \multirow[t]{7}{*}{ April } & 2 & $2 \cdot 7$ & $4 \cdot 26$ & $4 \cdot 06$ \\
\hline & 7 & 6.9 & 6.73 & $6 \cdot 65$ \\
\hline & 10 & $6 \cdot 4$ & $5 \cdot 8$ & $5.97^{1}$ \\
\hline & 12 & $7 \cdot 5$ & $7 \cdot 75$ & $7 \cdot 25$ \\
\hline & 13 & $5 \cdot 5$ & $7 \cdot 05$ & $6 \cdot 18$ \\
\hline & 17 & $7 \cdot 1$ & $9 \cdot 20$ & \\
\hline & 24 & $6 \cdot 9$ & $7 \cdot 38$ & 6.91 \\
\hline \multirow[t]{4}{*}{ May } & 1 & $10 \cdot 2$ & $9 \cdot 89$ & $9 \cdot 2$ \\
\hline & 9 & $14 \cdot 5$ & $10 \cdot 4$ & $10 \cdot 2$ \\
\hline & 19 & $8 \cdot 5$ & $10 \cdot 86$ & $10 \cdot 38$ \\
\hline & & $14 \cdot 4$ & & \\
\hline Aug. & $\begin{array}{r}23 \\
8\end{array}$ & & $\begin{array}{l}15 \cdot 7 \\
15\end{array}$ & $\begin{array}{r}9 \cdot 5 \\
10 \cdot 5\end{array}$ \\
\hline
\end{tabular}

follows more or less closely the mean air-temperature for the intervening period between successive estimations. The vernal rise in soil-temperature is clearly shown during this period, but the chief point of interest is the

1 The higher temperature of the uncoppiced area in these two cases was probably due to shelter effect since high winds had prevailed during the intervening period. 


\section{The Oak-Hornbeam Woods of Hertfordshire}

almost uniformly higher temperature of the soil, at this depth, in the coppiced part as compared with the uncoppiced. This difference seems best explained on the ground that, the shrub layer in the uncoppiced part, by cutting off nearly 60 per cent. of the direct sunlight, greatly retards the heating up of the surface layers.

It is doubtless the upward gradient of the soil-temperature that largely determines the rate of development of the vegetation. In this connection the difference between the coppiced and uncoppiced parts is significant. For observations, over a period of years, seem to indicate that the time of flowering of the vernal species in a coppiced wood is nearly always in advance of the same species in an uncoppiced wood, and this in spite of the increased exposure. Thus, on the 20th of March, 1912, Anemone nemorosa was in full bloom in a coppiced wood, whereas in an adjacent uncoppiced one with no more exposure only one specimen was in bloom, whilst the remainder were in bud. The same feature was also exhibited by Ficaria verna.

\section{(6) Comparison with the Oak-Hazel Woods.}

As the oak-hazel woods of Hertfordshire have as yet been only partially worked out, the remarks here made must necessarily be of a somewhat tentative character. However, it may here be stated that the results so far obtained indicate that the oak woods with a Corylus shrub layer are confined to the heavier soils or on the lighter types where these are shallow so that consequently the chalk is close to the surface. As might be expected the damp societies are better represented and the following shade species appear to be more generally common: Adoxa moschatellina, Ajuga reptans, Asperula odorata, Arum maculatum, Circaea lutetiana, Mercurialis perennis, Nepeta glechoma, Primula acaulis and Veronica montana.

On the whole the shade-flora of the oak-hazel wood is more abundant both as to species and individuals, and this appears to be associated with a greater intensity of light during the "light-phase."

In the coppice society, Euphorbia amygdaloides, Hypericum perforatum and Lychnis dioica are often abundant, the last named being particularly characteristic. Amongst species of rare occurrence in the county, and which are almost or entirely confined to oak-hazel woods, may be mentioned Dentaria bulbifera, Allium ursinum, Lathraea squamaria and Vinca minor.

These few facts are sufficient to show that the oak-hornbeam is a subassociation quite distinct from the oak-hazel type in the composition of its flora. Even in the tree layer the greater prevalence of Ulmus glabra and Prunus avium in the oak-hazel woods constitutes a distinctive feature. 
JOURNAL OF ECOLOGY

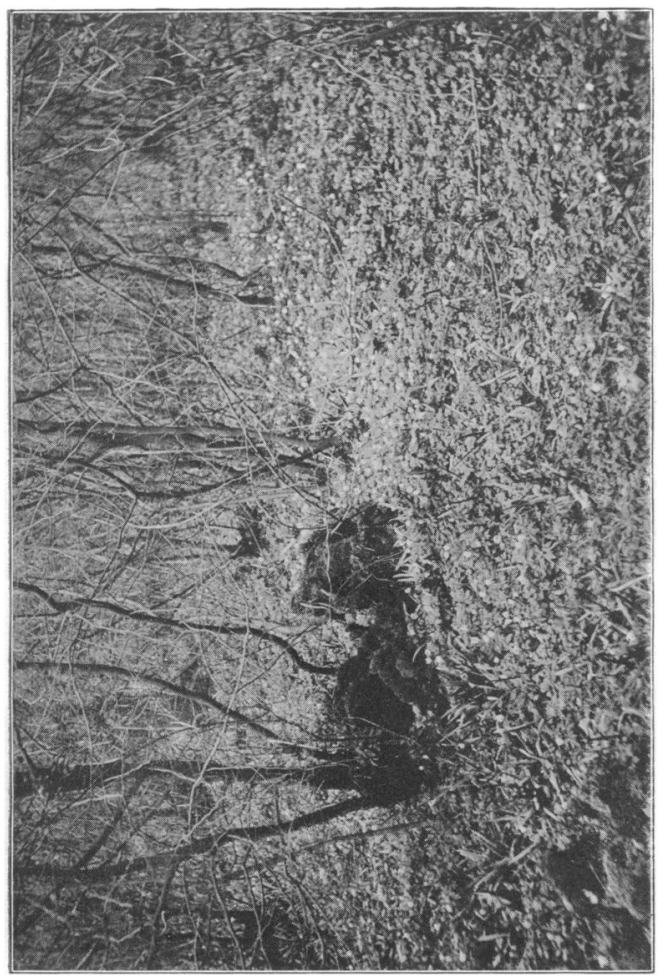

Vol. IV, Plate IX
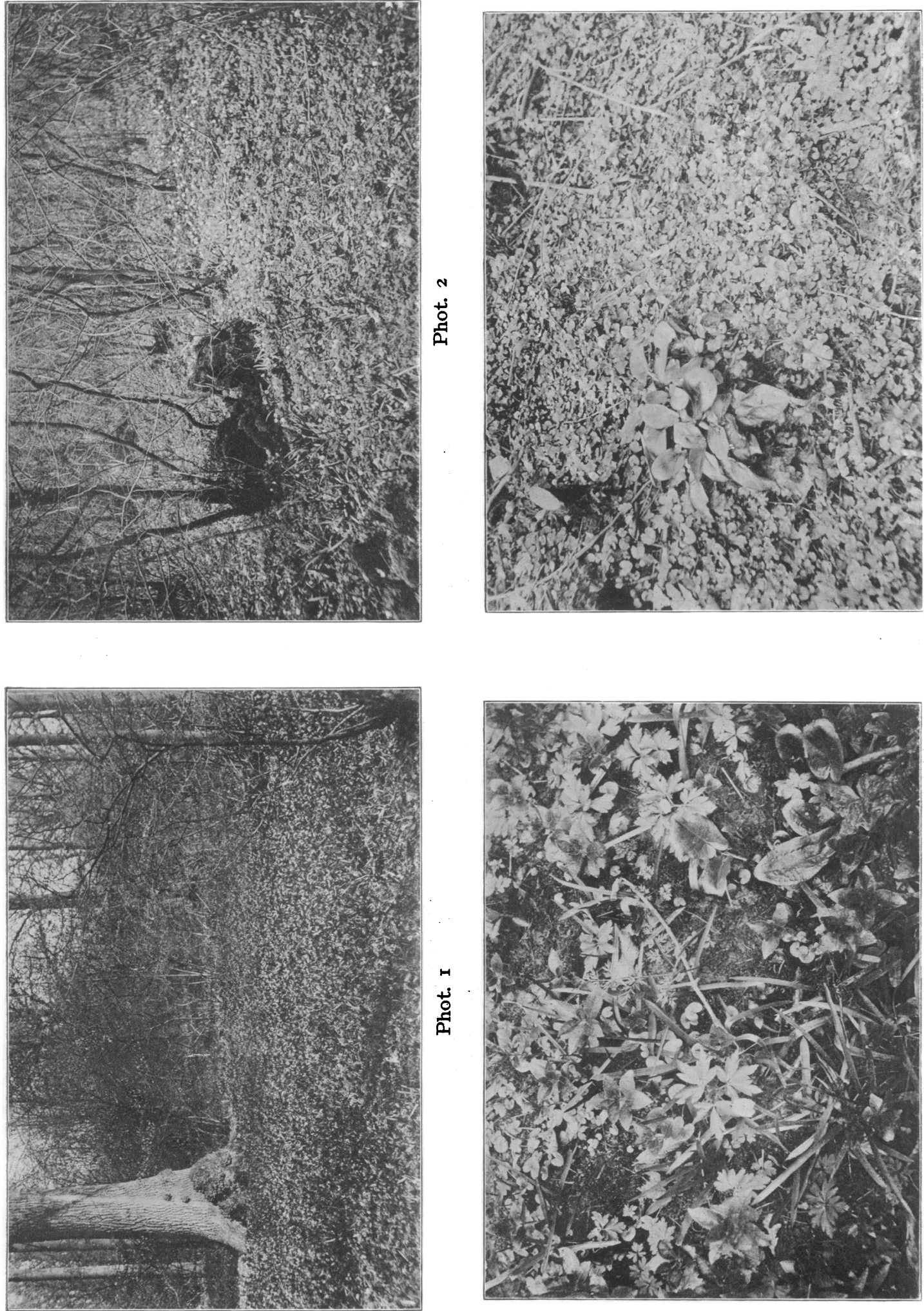

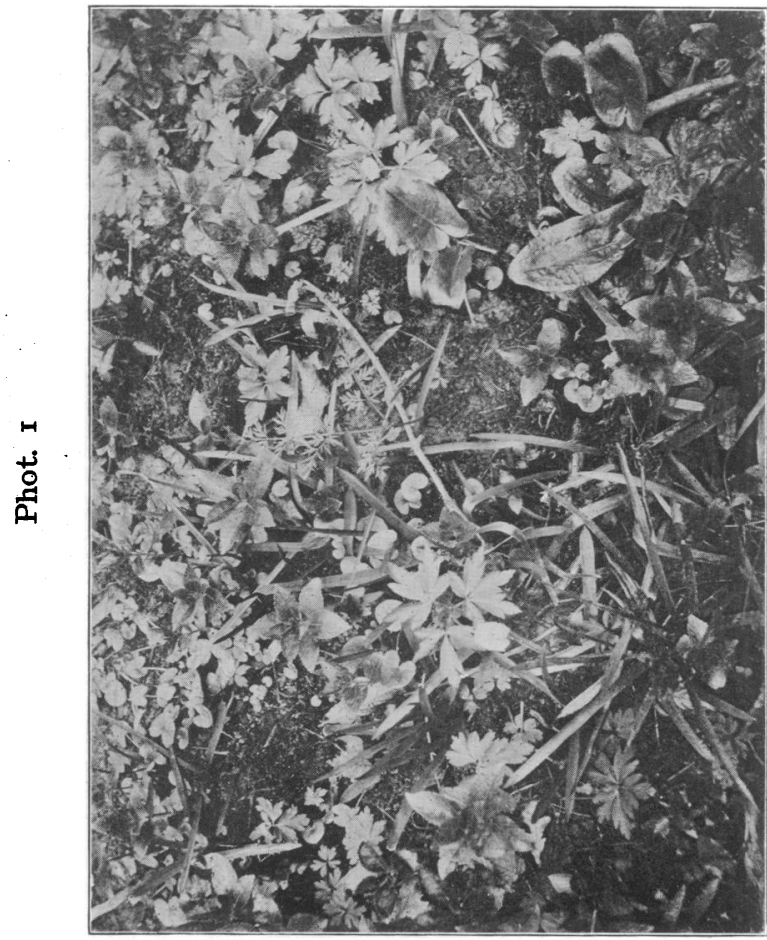

$$
\text { | }
$$



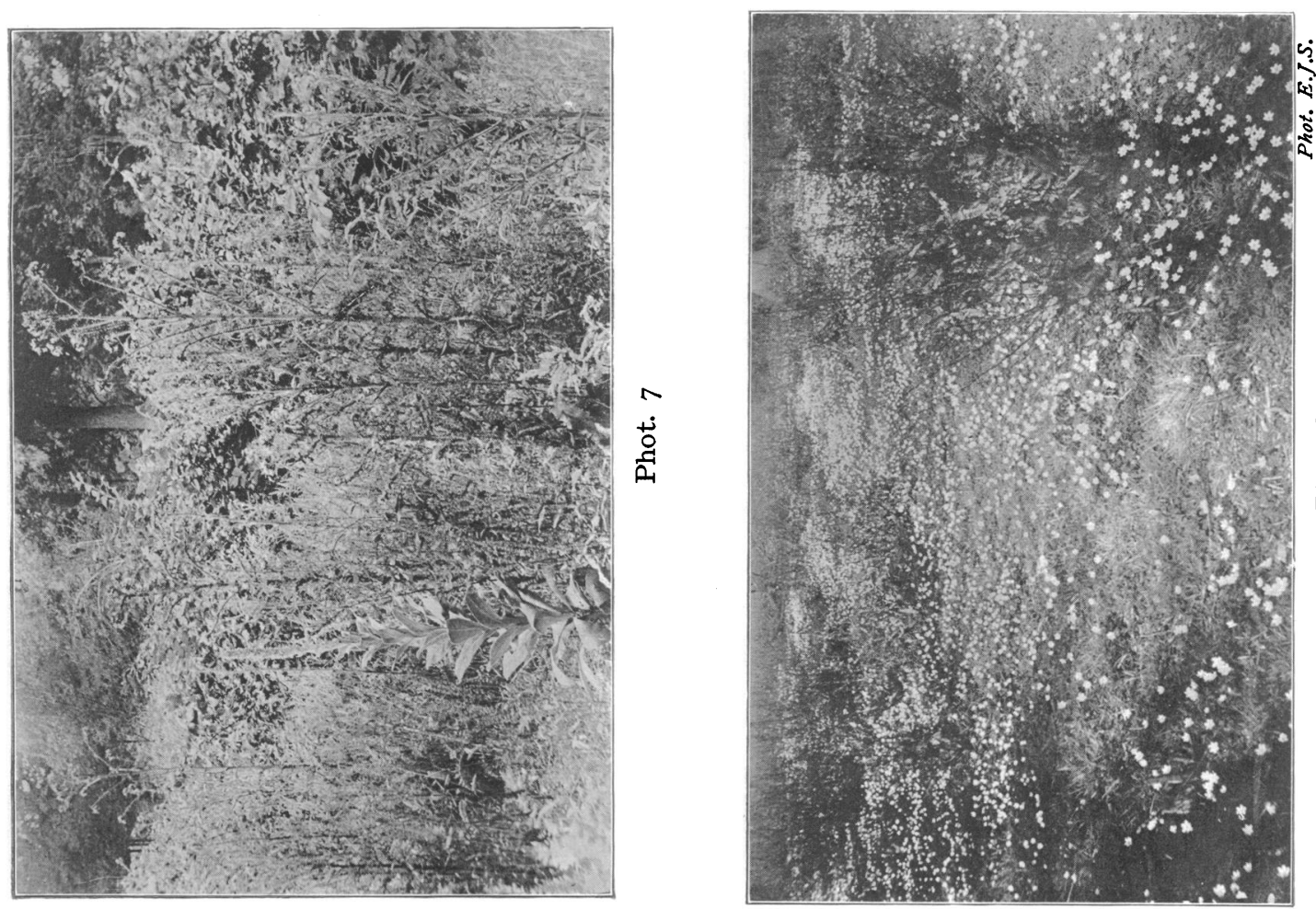

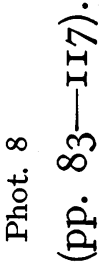
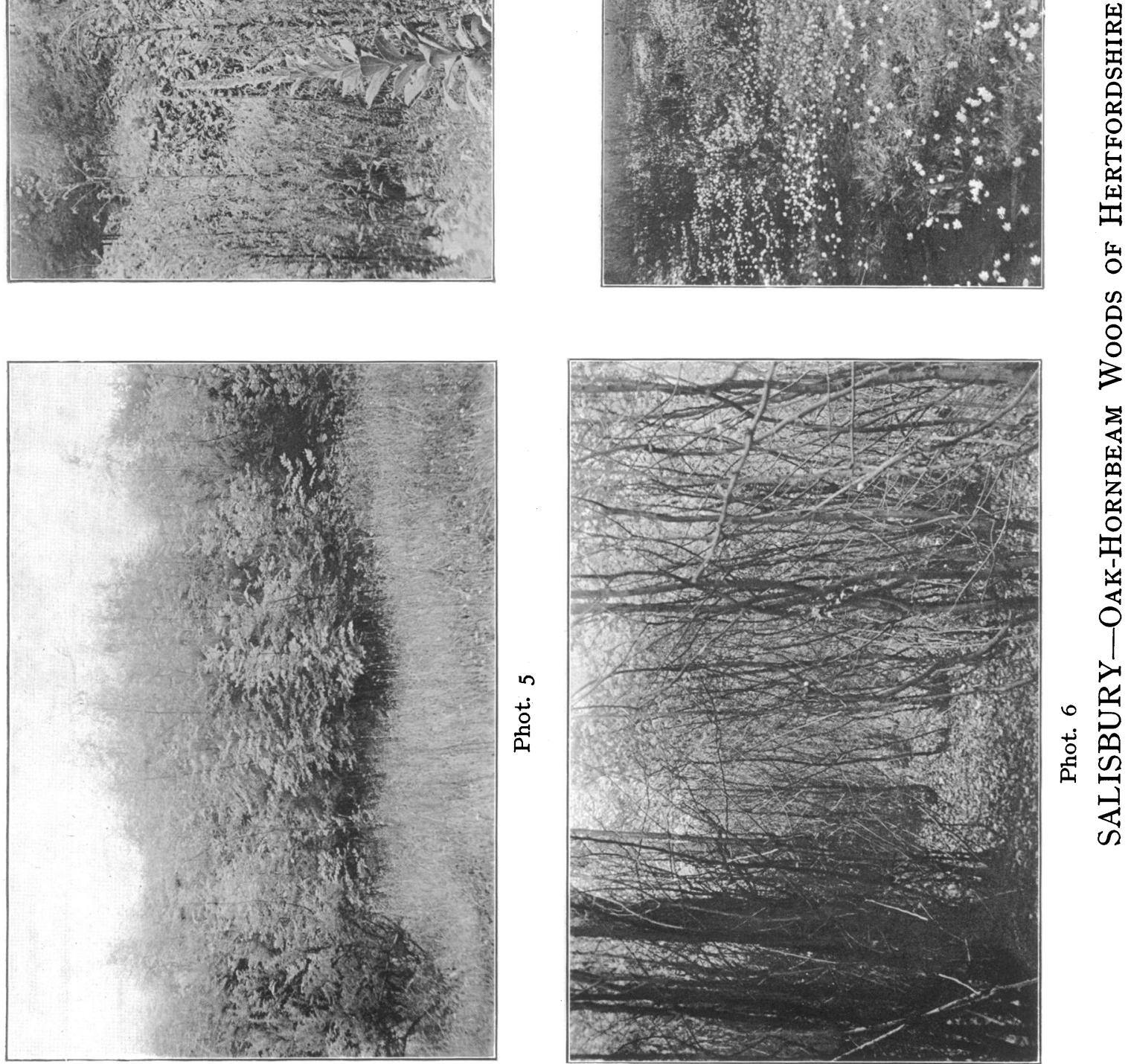


\section{(7) Conclusion. Summary of Societies.}

No general summary will be given here as it is proposed to epitomise the main results at the end of Part III, when comparison with the Quercus sessiliflora-Carpinus woods will be made. The chief ground societies and their relation to the undergrowth and other factors may however be conveniently summarised as under:

\begin{tabular}{|c|c|c|c|c|}
\hline Shrub layer & Society & \multicolumn{3}{|c|}{ Soil factors } \\
\hline $\begin{array}{lccc}\text { Carpinus } & \ldots & \ldots & \ldots \\
\text { Carpinus, } & \text { Corylus, } & \text { Sambucus... }\end{array}$ & $\left.\begin{array}{l}\text { Pteris } \\
\text { Anemone } \\
\text { Mercurialis }\end{array}\right\}$ & $\begin{array}{l}\text { High acidity } \\
\text { Low acidity }\end{array}$ & $\begin{array}{l}\text { Dry wit } \\
\text { organic }\end{array}$ & $\begin{array}{l}\text { h low } \\
\text { content }\end{array}$ \\
\hline Carpinus and Corylus ... & $\left\{\begin{array}{c}\text { Mercurialis } \\
\text { Ficaria } \\
\text { Ranunculus } \\
\text { repens }\end{array}\right.$ & $\begin{array}{l}\text { Shade } \\
\text { Deep shade } \\
\text { Deep shade }\end{array}$ & $\left\{\begin{array}{l}\text { Damp } \\
\text { Very } \\
\text { damp }\end{array}\right\}$ & $\begin{array}{c}\text { High } \\
\text { organic } \\
\text { content }\end{array}$ \\
\hline & $\begin{array}{l}\text { Marginal } \\
\text { society } \\
\text { Path society }\end{array}$ & $\begin{array}{l}\text { Together wit } \\
\text { shade-flo } \\
=\text { Society of }\end{array}$ & $\begin{array}{l}\text { h weeds } \\
\text { ra } \\
\text { coppiced }\end{array}$ & \\
\hline
\end{tabular}

\section{DESCRIPTION OF PHOTOGRAPHS ON PLATES IX AND $X$}

\section{PLATE IX}

Phot. 1. Mercurialis perennis society, Langley Wood, occupying damp ground in portion of wood without shrub layer. Other species present are Scilla nutans and Ficaria verna. April 19th. See pp. 101 and 103.

Phot. 2. Anemone nemorosa society, Stocking's Wood. Other species present are Conopodium denudatum and Scilla nutans. April 18th. See p. 101.

Phot. 3. Mixed society, Stocking's Wood, occupying the transition region between a damp society dominated by Mercurialis perennis and a dry society dominated by Anemone nemorosa. Most of the commonest shade species are present, viz. Ficaria verna, Scilla nutans, Anemone nemorosa, Conopodium denudatum, Arum maculatum. Between the phanerogams can be seen Eurhynchium rusciforma forming an almost continuous carpet. April 18th. See p. 101.

Phot. 4. Ficaria verna society, Clapper's Wood. The only other species present are Arum maculatum and a single shoot of Mercurialis perennis. Marcb. See p. 103.

\section{PLATE X}

Phot. 5. Rough pasture near an oak-hornbeam wood (Well Wood) colonised by numerous saplings of Fraxinus excelsior. To right and left are seen bushes of Ulex europaeus. See p. 98.

Phot. 6. Interior of Clapper's Wood, photographed the year before coppicing, showing the very sparse ground-flora. Coppice about 16 years old. See p. 97.

Phot. 7. Clapper's Wood, two years after coppicing, showing the abundant vegetation. Chief species present Cnicus palustris, Holcus lanatus, Verbascum thapsus, Rumex condylodes and on the right Cnicus lanceolatus. June 29th. See p. 112.

Phot. 8. Stocking's Wood, one year after coppicing, showing the profusion of flowers of Anemone nemorosa. Compare with Plate IX, Phot 2, from same wood before coppicing. In the foreground are seen numerous tussocks of Holcus lanatus. April 10th. See p. 96 . 